\title{
7. SITE 472: BAJA CALIFORNIA SEAMOUNT PROVINCE ${ }^{1}$
}

\author{
Shipboard Scientific Party ${ }^{2}$
}

\section{HOLES 472, 472A}

Date occupied: 18 November 1978 (472); 20 November 1978 (472A)

Date departed: 20 November 1978 (472, 472A)

Position: $23^{\circ} 00.35^{\prime} \mathrm{N}, 113^{\circ} 59.71^{\prime} \mathrm{W}(472,472 \mathrm{~A})$

Water depth (sea level; corrected m, echo-sounding): 3831 (472, 472A)

Bottom felt (m, drill pipe): 3847.5 (472, 472A)

Penetration (m): 137.5 (472); 94.5 (472A)

Number of cores: 16 (472); 1 (472A)

Total length of cored section $(\mathrm{m}): 137.5(472) ; 0.2(472 \mathrm{~A})$

Total core recovered $(\mathrm{m}): 65.11(472) ; 0.2(472 \mathrm{~A})$

Core recovery $(\%): 47$ (472); $100(472 \mathrm{~A})$

Oldest sediment cored (472):

Depth sub-bottom (m): 112

Nature: Nannofossil ooze

Chronostratigraphy: Middle Miocene $(15 \pm 0.5$ m.y. $)$

Basement (472):

Depth sub-bottom (m): 112

Nature: Pillow basalt

Principal results: Unit 1 , moderate yellowish brown pelagic clay deposited from the early Quaternary to late Miocene, was recovered from the mudline to sub-bottom depth of 24.5 meters. This unit is underlain by upper and middle Miocene greenish gray clayey diatomaceous ooze and pelagic clay to 91 meters (Unit 2). Unit 3 is composed of diatomaceous nannofossil ooze with minor vitric ash; metalliferous, dolomitic nannofossil ooze occurs at the base (at $112 \mathrm{~m}$ ). The oldest sediment above basalt was deposited in the middle Miocene $15 \pm 0.5$ m.y. ago and is assigned to the Sphenolithus heteromorphus Zone. Unit 1 is almost barren of fossils and grades into Unit 2, indicated by the increase in siliceous microfossils. The absence of calcareous microfossils in these two units suggests deposition below the carbonate compensation depth (CCD). Sediment accumulation rates are about $5 \mathrm{~m} / \mathrm{m} . \mathrm{y}$. in sediments younger than about $7 \mathrm{~m} . y$. , and $8 \mathrm{~m} / \mathrm{m} . \mathrm{y}$. in older sediments. One heat-flow measurement at 88 meters was $14.3^{\circ} \mathrm{C}$; sediment density is $1.5 \mathrm{~g} / \mathrm{cm}^{3}$ and velocity $1.5 \mathrm{~km} / \mathrm{s}$.

Basement is olivine-plagioclase basalt with well-developed quench texture; 11 different cooling units (pillows) were recog-

\footnotetext{
1 Initial Reports of the Deep Sea Drilling Project, Volume 63.

${ }^{2}$ Robert S. Yeats (Co-Chief Scientist), Department of Geology, Oregon State University, Corvallis, Oregon; Bilal U. Haq (Co-Chief Scientist), Department of Geology and Geophysics, Woods Hole Oceanographic Institution, Woods Hole, Massachusetts; John A. Barron, U.S. Geological Survey, Menlo Park, California; David Bukry, U.S. Geological Survey, La Jolla, California; James K. Crouch, U.S. Geological Survey, Menlo Park, California (present address: Sohio Petroleum Co.. San Francisco, California); Charles Denham, Department of Geology and Geophysics, Woods Hole Oceanographic Institution, Woods Depart Neos Acweastle-upon-Tyne, United Kingdom, Nadimir I. Grechin, Geological Institute of the Academy of Sciences of the U.S.S.R., Moscow, U.S.S.R.; Margaret Leinen, Graduate School of Oceanography, University of Rhode Island, Kingston, Rhode Island; Alan R. Niem, Department of Geology, Oregon State University, Corvallis, Oregon; Surendra Pal, Instituto de Geof́́sica, Universidad Nacional Autónoma de Mexico, Mexico 20, D.F.; Kenneth A. Pisciotto, Deep Sea Drilling Project, Scripps Institution of Oceanography, La Jolla, California; Richard Z. Poore, U.S. Geological Survey, Menlo Park, California; Tsugio Shibata, Department of Earth Sciences, Okayama University. Tushima, Okayama, Japan: and Reinhard Wolfart, Bundesanstalt fiir Geowissascha and Reinhard Wolfart, Bundesanstalt für Geowissenschaften und Rohstoffe, Hannover
Federal Republic of Germany.
}

nized. Rare intercalations of middle Miocene limestone were found in Core 15 .

At Hole $472 \mathrm{~A}$ the drill pipe was raised above the mudline and washed down to obtain a second heat-flow reading below 100 meters. Unfortunately, basalt was reached at 94.5 meters, 17.5 meters shallower than in the original hole. A 20 -cm basalt core was recovered.

\section{BACKGROUND AND OBJECTIVES}

Site 472 was proposed at about $23^{\circ} \mathrm{N}$ and $114^{\circ} \mathrm{W}$ to obtain a pelagic upper Neogene record at this latitude free from terrigenous influences, such as those affecting Site 471 (Figs. 1 and 2). This goal was especially important in view of the fragmentary paleontological record obtained at Site 471 . The proposed site was expected to yield a well-preserved siliceous and calcareous microfauna and -flora for most of the upper Neogene beyond the influence of the eastern boundary current and possible terrestrial input. It was selected to complement Site 471 and to complete a north-south latitudinal transect in various climatic and circulatory regions.

Site 471 was thought to be located on oceanic crust about $11 \mathrm{~m} . \mathrm{y}$. of age, according to a projection of striped magnetic anomalies described by Chase et al. (1970) (Fig. 3). The low amplitude of north-south magnetic stripes at this low latitude, however, makes magnetic correlations somewhat speculative in this area. On the basis of paleontological data, the crust at this site should be much older, about $15 \mathrm{~m} . \mathrm{y}$. of age; thus the tectonics west of southern Baja California may be more complex than previously believed.

South of the Clarion fracture zone, the Mathematician Ridge represents a fossil rise crest abandoned about 5 m.y. ago for the present East Pacific Rise crest farther east (Sclater et al., 1971; Fig. 4). North of the Clarion, the area around Site 472 has relatively high heat flow for a site so far west of the present rise crest (Fig. 4). The anomalous bulge in the western flank of the East Pacific Rise in the area of the Suitcase seamounts (Fig. 2) may represent a northern continuation of the abandoned Mathematician rise crest, and the rugged topography and offset of the 2100 -fathom contour may indicate a fracture zone between those of the Clarion and the Molokai. We anticipated that the basement age at Site 472 would shed light on the interpretation of these features.

We planned to sail about 100 miles west of Site 471 across an existing Challenger Leg 54 reflection profile. Our strategy was to locate a site a short distance west of the Challenger Leg 54 line on fairly flat abyssal-hill topography with about 200 meters of sediments. The proposed location would put us on a magnetic anomaly 


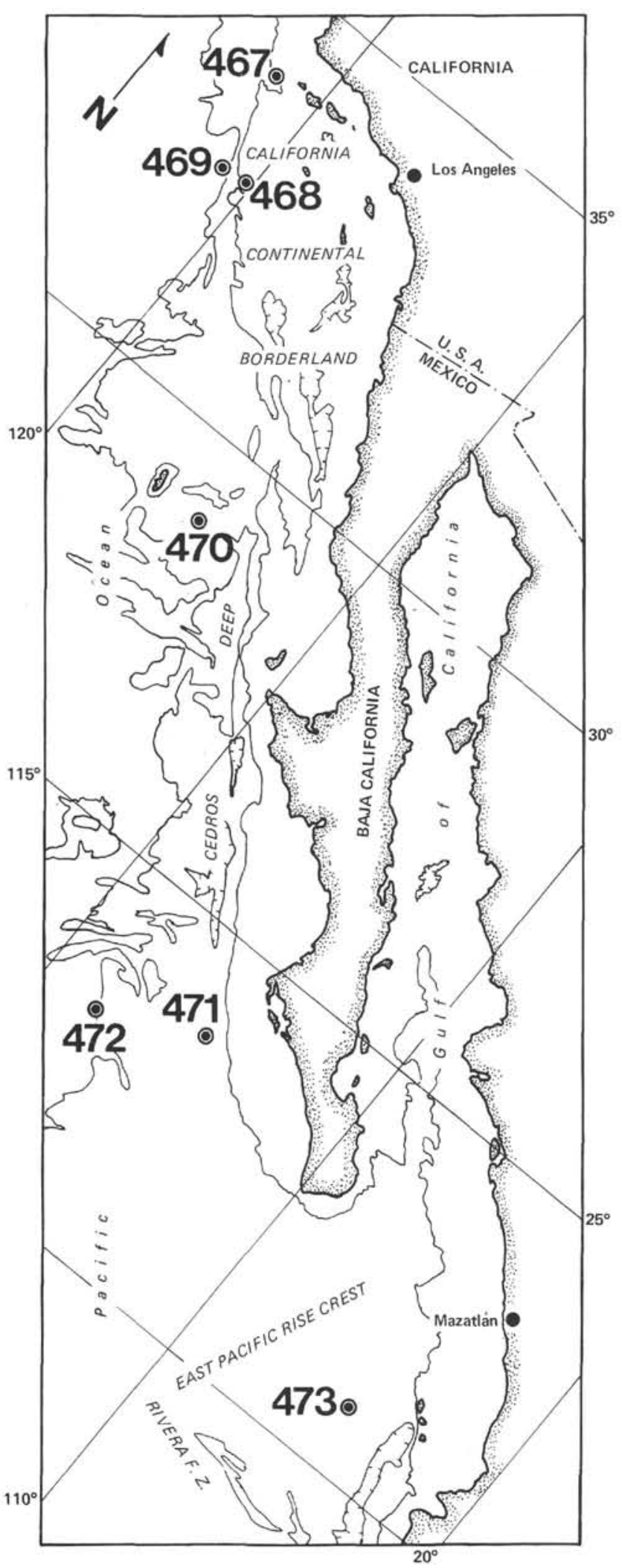

Figure 1. Location of Leg 63 sites. with a crustal age of 14 m.y. (Fig. 3), according to paleomagnetic interpretations of Chase et al. (1970).

\section{OPERATIONS}

We steamed west from Site 471 to examine a normal, low-latitude pelagic sediment section on crust with reliable magnetics. Near $23^{\circ} \mathrm{N}, 114^{\circ} \mathrm{W}$, we found a small plateau on our westward pass, and we returned about a mile to the north to get a mirror image of our westward track. We then turned west again on our old track and dropped the beacon at 0056 hours, ${ }^{3} 18$ November 1978 (Fig. 5).

We ran into difficulty when the bumper subs jarred several hundred meters above precision depth recorder (PDR) bottom on the way into the hole. A stand of pipe was being picked up at the time the bumper subs took weight. We then continued running pipe and spudded the hole close to PDR depth.

Coring was routine (Table 1), except for operational problems: the vertical reference gyro was switched because of erratic positioning, and the bottom blew out of the starboard Bowen hydraulic pump, requiring replacement with a spare unit. We took a heat-flow measurement at 88 meters and planned another one at around 115 meters, but instead encountered fresh basalt at 112 meters. Basalt was cored to 137.5 meters, with low core recovery and intermittent pipe sticking.

In hopes of getting a second heat-flow measurement at 105 meters, we raised the pipe above the mudline and washed down Hole 472A. However, basalt was encountered at 94.5 meters, $\mathbf{1 7 . 5}$ meters shallower than in the Hole 472 , so we abandoned the site.

\section{LITHOLOGY}

\section{Sediments and Sedimentary Rocks}

Site 472 is dominated by biogenic sediments and consists mainly of diatomaceous and siliceous clay, diatomaceous and nannofossil ooze, clay, and minor metaliferous sediment. These sediments are divided into three lithologic units (Fig. 6; Table 2).

\section{Unit 1: Clay (0-24.5 m)}

Unit 1 consists of firm to compact clay with trace amounts of siliceous microfossils. The clay is yellowish brown and mottled with scattered grayish brown to olive gray patches and vertical streaks. The darker colors are probably the result of higher proportions of finely disseminated opaque aggregates. Thin layers of greenish gray clay are present as a minor lithology in this unit (Samples 472-2-5, 50-70 cm; Sample 472-3-3, $30-70 \mathrm{~cm}$ ). These layers have sharp contacts with overlying and underlying yellowish brown clay that has been disturbed by drilling.

\footnotetext{
${ }^{3}$ Times specified in the text are local times in hours; those in seismic-section figures are Zulu (Z) times.
} 


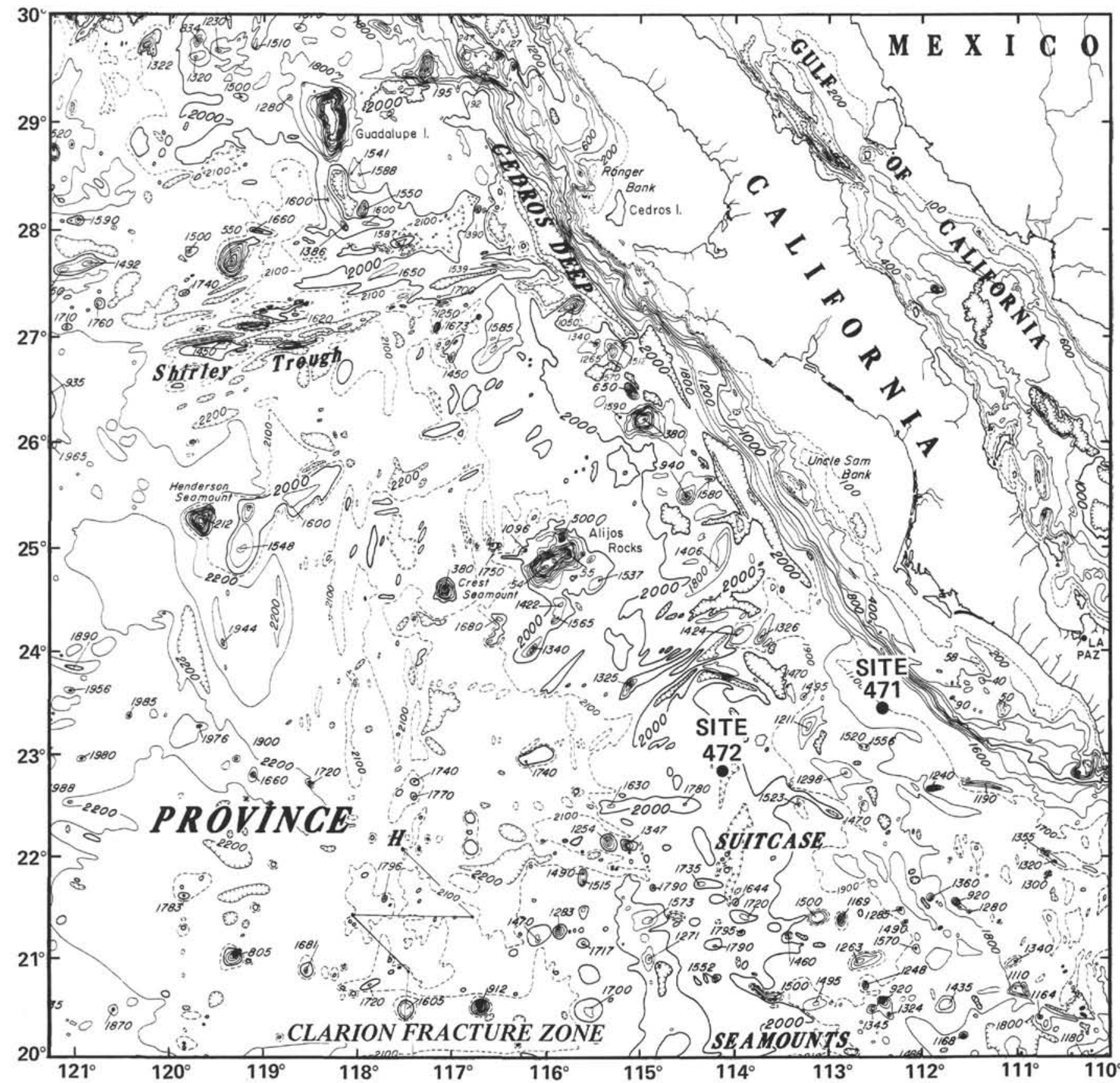

Figure 2. Bathymetric map showing location of Sites 471 and 472 off southern Baja California (Chase et al., 1974).

Unit 1 is composed of about $95 \%$ clay minerals. Siltsize angular quartz, feldspar, micas, brown volcanic glass, and opaque aggregates and pyrite are present as accessory constituents. A few diatoms, sponge spicules, radiolarians, and silicoflagellates also occur.

\section{Unit 2: Diatomaceous Ooze and Clay (24.5-91 m)}

This unit forms the thickest sedimentary interval $(66.5 \mathrm{~m})$ at this site. Greenish gray clayey diatomaceous ooze and light olive gray diatomaceous clay are the dominant lithologies. Minor lithologies include clay, diatomaceous ooze, and siliceous clay. These minor lithologies are more abundant in the lower and upper- most parts of the unit. Unit 2 contains many reduction streaks and patches of grayish purple manganese oxide or finely disseminated pyrite that have been distorted by drilling. Small scattered patches and streaks of grayish yellow green to pale olive vitric ash also occur in Cores 9 and 10.

The upper contact of this unit is defined by an abrupt color change from yellowish brown (Core 3 ) to greenish gray (Core 4) as well as by a dramatic increase of siliceous microfossils in Cores 4 and 5 . In Core 4, the clay is dominant, but it decreases sharply in Core 5 where diatoms (circa 5-70\%), radiolarians 3-15\%), silicoflagellates (up to $10 \%$ ), and sponge spicules (up to $5 \%$ ) 


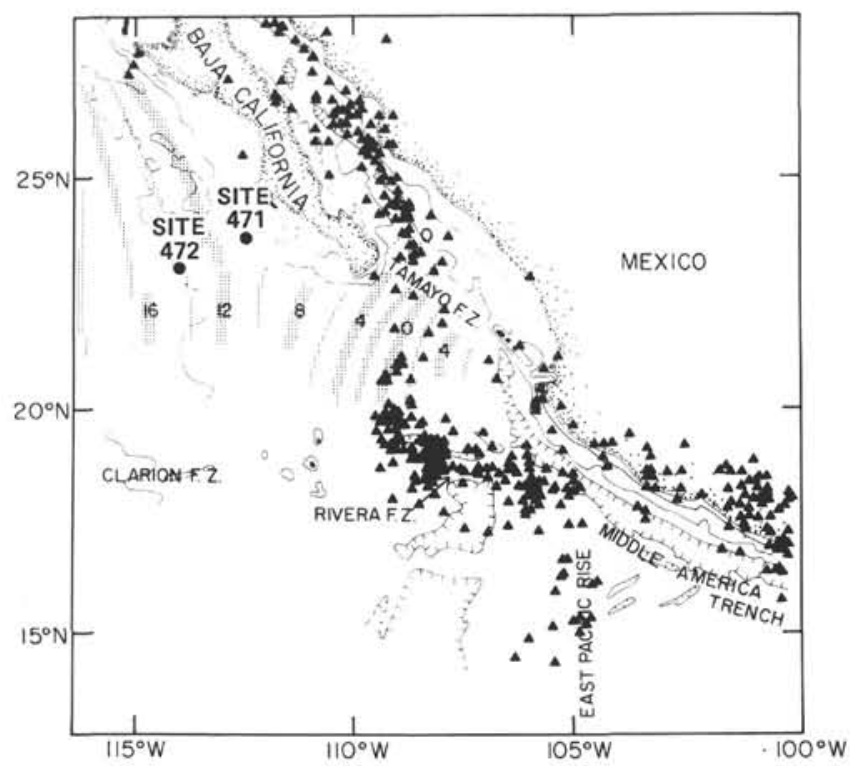

Figure 3. Earthquake epicenters and sea-floor age at the mouth of the Gulf of California (after Atwater [1970] and Chase et al. [1970]). (The magnetic-anomaly age at Site 472 is about 14 m.y. old.) become the major sedimentary components. Nannofossils and foraminifers are almost absent in this unit. Near the base of the unit (Cores 9 and 10), clay again becomes the dominant component. Accessory components include quartz, feldspar, volcanic glass, mica, glauconite, and heavy minerals (including pyrite). The lower contact of Unit 2 is gradational. It occurs at the top of Core 11 where nannofossil abundance increases sharply.

\section{Unit 3: Nannofossil Ooze and Diatomaceous Clay (91-112 m)}

Unit 3 consists of greenish gray to light gray diatomnannofossil ooze, dark greenish gray nannofossil-diatomaceous clay, and grayish green siliceous-nannofossil clay. The ooze and clay contain up to $5 \%$ silt-size quartz and volcanic glass as well as traces of mica, pyrite, feldspar, and glauconite.

Minor lithologies in Unit 3 include greenish gray siliceous, clayey nannofossil ooze and yellowish brown to grayish orange clay. Small scattered patches and streaks of pale yellowish brown vitric ash and grayish blue green, glauconitic siliceous clay also occur. There is a small patch of nannofossil clay containing $3 \%$ glauco-

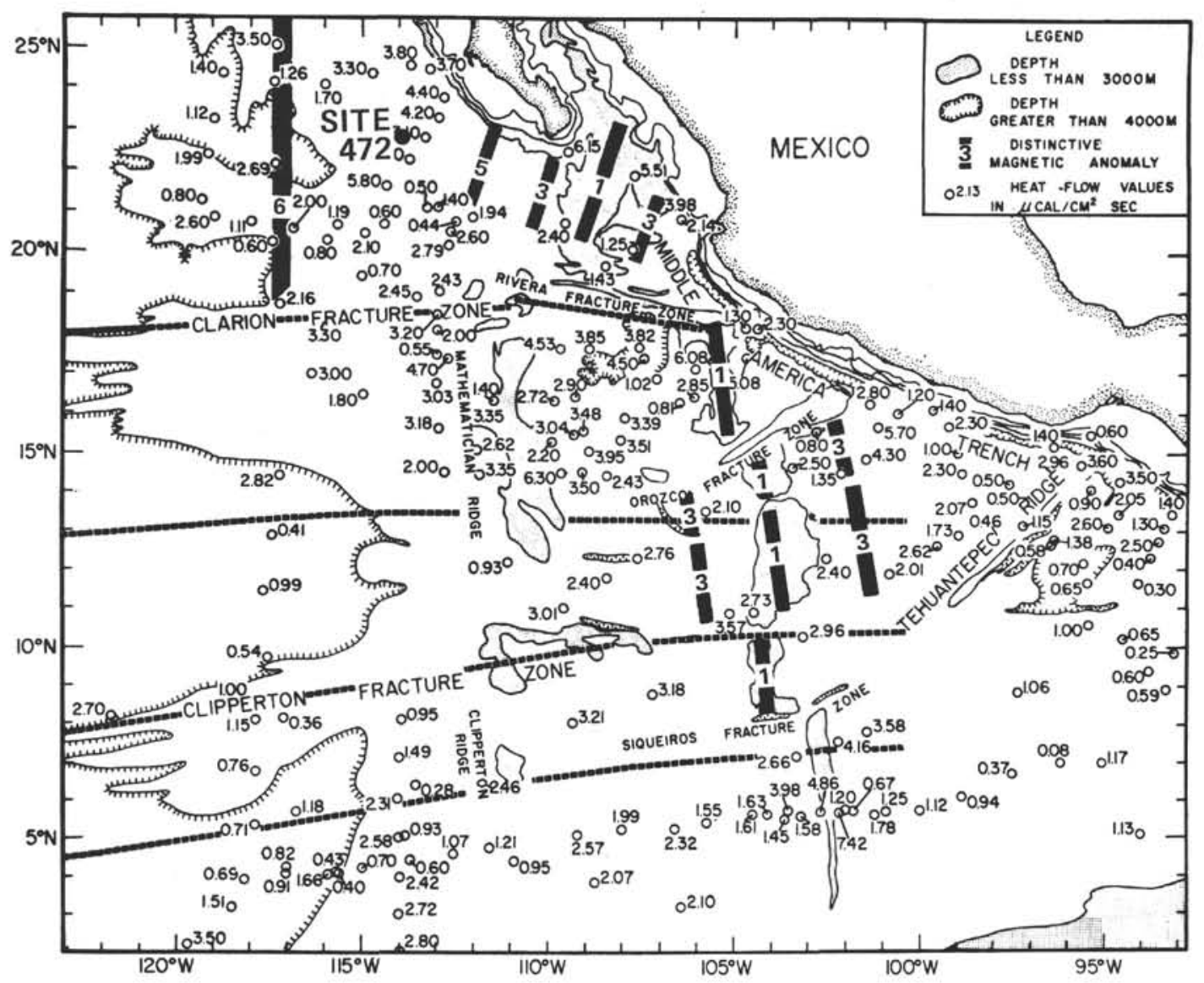

Figure 4. Heat-flow map of the eastern Pacific (after Sclater et al., 1971). (The Mathematician Ridge is an abandoned crest of the East Pacific Rise. Note high heat-flow values at Site 472.) 


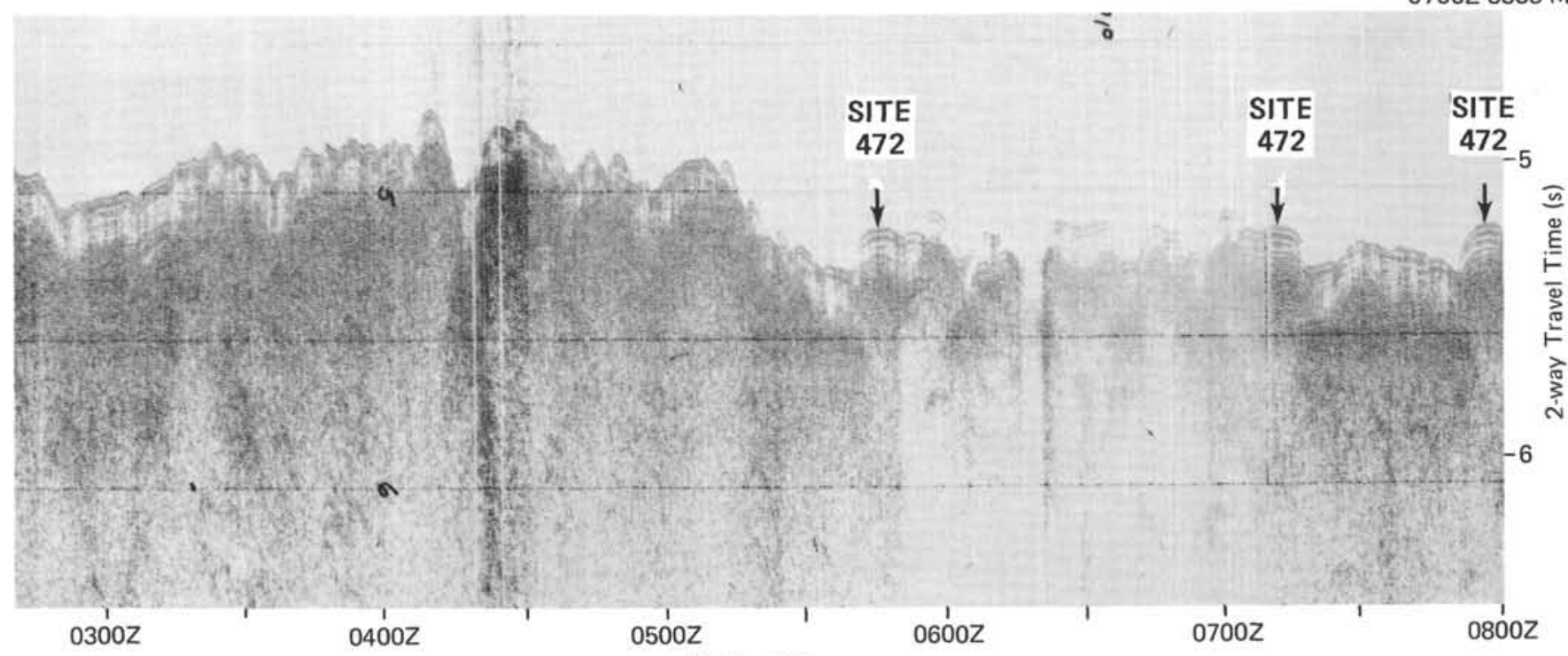

18 Nov. '78

Figure 5. Challenger seismic profile approaching Site 472.

Table 1. Coring summary, Site 472.

\begin{tabular}{|c|c|c|c|c|c|c|c|}
\hline $\begin{array}{l}\text { Core } \\
\text { No. }\end{array}$ & $\begin{array}{l}\text { Date } \\
\text { (Nov. } \\
\text { 1978) }\end{array}$ & Time & $\begin{array}{l}\text { Depth from } \\
\text { Drill Floor } \\
\text { (m) }\end{array}$ & $\begin{array}{l}\text { Depth below } \\
\text { Sea Floor } \\
\text { (m) }\end{array}$ & $\begin{array}{l}\text { Length } \\
\text { Cored } \\
\text { (m) }\end{array}$ & $\begin{array}{l}\text { Length } \\
\text { Recovered } \\
\text { (m) }\end{array}$ & $\begin{array}{c}\text { Core } \\
\text { Recovered } \\
(\%)\end{array}$ \\
\hline \multicolumn{8}{|c|}{ Hole 472} \\
\hline 1 & 18 & 1240 & $3847.5-3853.0$ & $0.0-5.5$ & 5.5 & 5.33 & 97 \\
\hline 2 & 18 & 1336 & $3853.0-3862.5$ & $5.5-15.0$ & 9.5 & 7.37 & 78 \\
\hline 3 & 18 & 1443 & $3862.5-3872.0$ & $15.0-24.5$ & 9.5 & 4.48 & 47 \\
\hline 4 & 18 & 1546 & $3872.0-3881.5$ & $24.5-34.0$ & 9.5 & 2.03 & 21 \\
\hline 5 & 18 & 1652 & $3881.5-3891.0$ & $34.0-43.5$ & 9.5 & 2.85 & 30 \\
\hline 6 & 18 & 1756 & $3891.0-3900.5$ & $43.5-53.0$ & 9.5 & 6.65 & 70 \\
\hline 7 & 18 & 1908 & $3900.5-3910.0$ & $53.0-62.5$ & 9.5 & 6.80 & 72 \\
\hline 8 & 18 & 2013 & $3910.0-3919.5$ & $62.5-72.0$ & 9.5 & 4.81 & 51 \\
\hline 9 & 19 & 0112 & $3919.5-3929.0$ & $72.0-81.5$ & 9.5 & 5.82 & 61 \\
\hline 10 & 19 & 0445 & $3929.0-3938.5$ & $81.5-91.0$ & 9.5 & 2.71 & 29 \\
\hline 11 & 19 & 0557 & $3938.5-3948.0$ & $91.0-100.5$ & 9.5 & 5.86 & 62 \\
\hline 12 & 19 & 1030 & $3948.0-3957.5$ & $100.5-110.0$ & 9.5 & 4.32 & 45 \\
\hline 13 & 19 & 1205 & $3957.5-3959.5$ & $110.0-112.0$ & 2.0 & 0.05 & 3 \\
\hline 14 & 19 & 1526 & $3959.5-3967.0$ & $112.0-119.5$ & 7.5 & 1.66 & 22 \\
\hline 15 & 19 & 1843 & $3967.0-3976.0$ & $119.5-128.5$ & 9.0 & 2.51 & 28 \\
\hline 16 & 20 & 0015 & $3976.0-3985.0$ & $128.5-137.5$ & 9.0 & 1.86 & 21 \\
\hline Total & & & & & 137.5 & 65.11 & 47 \\
\hline \multicolumn{8}{|c|}{ Hole $472 \mathrm{~A}$} \\
\hline 1 & 20 & 1145 & $3941.8-3942.0$ & $94.3-94.5$ & 0.2 & 0.20 & 100 \\
\hline Total & & & & & 0.2 & 0.20 & 100 \\
\hline
\end{tabular}

nite and $5 \%$ pyrite in Core 11 . A few pebbles $(\sim 1-8 \mathrm{~cm}$ long) of manganese-oxide-coated olive gray silty claystone are present within the oozes in Cores 11 and 13 . Another salient feature of Unit 3 is the presence of two thin layers (6-9 $\mathrm{cm}$ thick) of grayish brown dolomitic nannofossil ooze near the base of this unit (Core 12). This sediment contains up to $25 \%$ dolomite rhombs.

Pillow basalt was encountered below the dolomitic ooze at 112 meters. A few thin yellowish green limestone interbeds $(<8 \mathrm{~cm}$ thick) and siliceous sedimentary fragments are present within the basalt sequence (in Core 15). These sedimentary rock fragments contain scattered, altered basaltic glass fragments presumably derived from the fragmentation of the adjacent pillows.

\section{Igneous Rocks}

Basaltic basement rocks encountered at Site 472 include hyaloclastitic breccias, slightly altered basaltic pillow lavas, and basalt pebbles. We define 11 cooling units in Cores 14, 15, and 16; each of these units is separated by glassy chilled margins or intercalated thin sediments (Fig. 7). Because of the poor recovery and the many pebble-size, unoriented fragments, these subdivisions of the basalt sequence are necessarily arbitrary and are not meant to carry any genetic implications, although each of the units in Core 15 could correspond fairly well to single basalt pillows. The top $80 \mathrm{~cm}$ of the basalt sequence at Site 472 are characterized by hyaloclastic breccia made up of angular basaltic glass and pillow margin fragments cemented with very light gray cryptocrystalline material (clay plus silica?). The rest of the basalt sequence is mainly basaltic pillow lavas and basaltic pebbles, with two sediment intercalations at 119.6 and 120 meters below the sea floor.

The basaltic pillow lavas and basaltic fragments are gray to dark gray and become brownish gray along fractures and the glassy chilled margins. Vesicles in these basalts are not abundant $(<2-3 \%)$, are generally small in size $(<0.5 \mathrm{~mm})$, and are commonly filled with calcite and clay minerals. The pillow basalts and pebble-size basaltic fragments are mostly massive and aphanitic, and no phenocrystic mineral is visible macroscopically. Viewed through a microscope, these basalts vary in texture from aphyric to porphyritic and glomeroporphyritic, with plagioclase and occasional olivine microphenocrysts. These microphenocrysts are generally euhedral and range in size from 0.2 to $1 \mathrm{~mm}$. The plagioclase microphenocrysts are normally zoned or have an optically homogeneous core of labradoritic composition with a thin rim of more sodic plagioclase. The ground- 


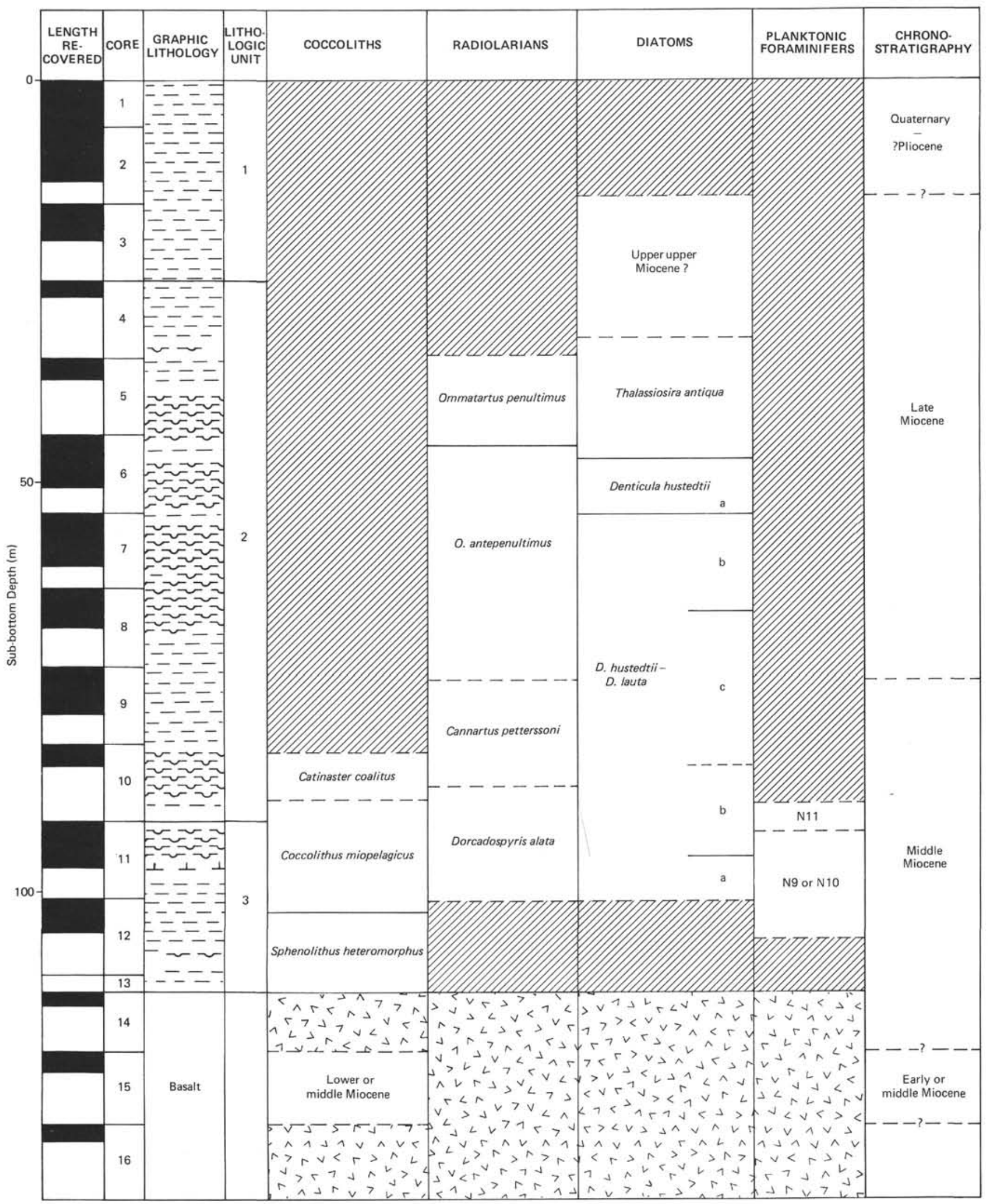

Figure 6. Lithologic and biostratigraphic summary, Site 472. 
Table 2. Summary of lithologic units, Site 472.

\begin{tabular}{|c|c|c|c|c|}
\hline Unit & $\begin{array}{c}\text { Core } \\
\text { Number }\end{array}$ & $\begin{array}{l}\text { Depth below } \\
\text { Sea Floor } \\
\text { (m) }\end{array}$ & Chronostratigraphy & Lithology \\
\hline 1 & $1-3$ & $0.0-24.5$ & \multirow{3}{*}{$\begin{array}{l}\text { lower Quaternary- } \\
\text { upper Miocene } \\
\text { upper Miocene } \\
\text { middle Miocene } \\
\text { middle Miocene }\end{array}$} & Clay. \\
\hline 2 & $4-10$ & $24.5-91.0$ & & Diatomaceous ooze and clay. \\
\hline 3 & $11-13$ & $91.0-112.0$ & & $\begin{array}{l}\text { Diatom-nannofossil ooze, } \\
\text { nannofossil diatomaceous } \\
\text { clay, and dolomitic } \\
\text { nannofossil ooze. }\end{array}$ \\
\hline
\end{tabular}

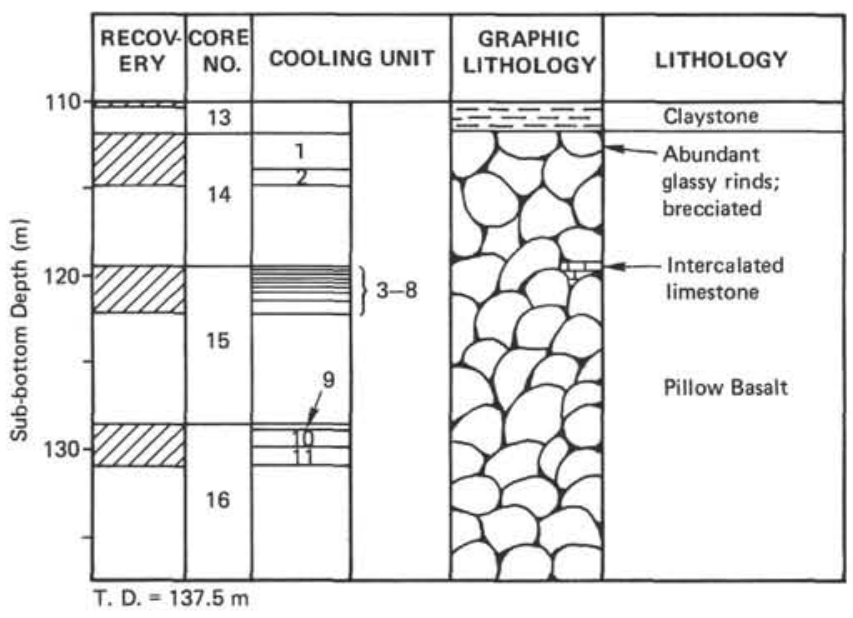

Figure 7. Igneous rock sequence at Site 472.

mass textures of specimens sampled from pillow margins vary from holohyaline to subvariolitic, and locally to hyalopilitic. The pillow interiors usually show an intergranular texture with minute mesostasis between plagioclase laths and equant clinopyroxenes. The specimens sampled from pillow margins are characterized by skeletal microlites of plagioclase and feathery clinopyroxene with well-developed quench morphology.

The glassy fragments found in the hyaloclastic breccia are mostly fresh and clear brown, though some are partly devitrified. They are angular and range in grain size from $1 \mathrm{~mm}$ to $5 \mathrm{~cm}$. Scattered euhedral plagioclase $(<2 \%)$ occurs commonly as a microphenocryst phase in these glassy fragments.

\section{BIOSTRATIGRAPHY}

At Site 472, lower Quaternary to (?)Pliocene red clay overlies upper upper Miocene diatomaceous clay, lower upper Miocene to upper middle Miocene diatomaceous ooze, and lower middle Miocene nannofossil-diatomaceous ooze. Figure 8 portrays microfossil abundances in Hole 472. Microfossil age control in the red clay is limited to the top of the hole (Sample 472-1-1, 1-2 cm), where Quaternary radiolarians are present. Rare to few diatoms and silicoflagellates in the core catchers of Cores 3 and 4 of Hole 472 are similar to those found in the upper upper Miocene at nearby Site 471. Abundant siliceous microfossils begin downhole in the lower part of Section 1 of Core 5, where upper Miocene diatoms and radiolarians are present. The middle Miocene/upper Miocene boundary lies within Core 9 at the boundary between the Ommatartus antepenultimus and Cannartus petterssoni (radiolarian) Zones. Calcareous nannofossils in Sample 472-10,CC and planktonic foraminifers in Sample 472-11,CC indicate deposition above the CCD. Sphenolithus heteromorphus Zone coccoliths in Cores 12 and 13 above the basalt suggest a basement age of about $16 \mathrm{~m} . \mathrm{y}$. Figure 6 summarizes zone assignments for Site 472 .

\section{Coccoliths}

Cores 1 to 9 of Hole 472 and Core 1 of Hole $472 \mathrm{~A}$ are barren of coccoliths. Middle Miocene coccolith assemblages, however, are common to abundant and moderately well preserved, ranging from the Sphenolithus heteromorphus Zone just above basalt in Core 13 (110$112 \mathrm{~m})$ to the Catinaster coalitus Zone in Core 10 (81.5-91 m). A limestone from Hole 472, Section 15-1, is the only coccolith-bearing sediment recovered from the basalt interval at either hole. The low-diversity assemblage is dominated by Cyclicargolithus floridanus (Roth and Hay) and represents a residuum of durable species that probably belongs to the overlying $S$. heteromorphus Zone. A S. heteromorphus Zone assemblage occurs in a black manganese-oxide fragment in the corecatcher sample of Core 13. The zone extends as high as Section 12-2 within dark brown clay beds.

The overlying Coccolithus miopelagicus Subzone ranges upsection from Core $12(100.5 \mathrm{~m})$ to Sample 472 $11-1,10 \mathrm{~cm}(91 \mathrm{~m})$. Cyclicargolithus floridanus is common throughout the subzone, suggesting that the top was not sampled. Catinaster coalitus Martini and Bramlette occurs in Sample 472-10,CC with Coccolithus sp. aff. C. miopelagicus Bukry, indicating the upper middle Miocene Catinaster coalitus Zone. Owing to poor recovery in Cores 10 and 11 or to a hiatus, the intervening Discoaster kugleri Subzone is missing.

\section{Silicoflagellates}

In Hole 472, silicoflagellates are sparse to common and well preserved in Miocene Cores 3 to 12 . The lowdiversity assemblages of the Dictyocha fibula Zone in Cores 3 to 5 (correlative with Cores 10 to 17 at Site 471) probably are upper Miocene on the basis of radiolarian dates at Site 471 (upper upper Miocene Stichocorys peregrina Zone). The assemblages are dominated by Dictyocha fibula Ehrenberg, D. brevispina (Lemmermann), and Distephanus speculum (Ehrenberg). Older Dictyocha pulchella Bukry is common in Cores 6 to 12 . Mid-latitude guide Distephanus pseudofibula (Schultz) occurs in Core 6; elsewhere low-latitude assemblages prevail. Panicoid and elongate opal phytoliths (microfossils from terrestrial grasses) also occur in Core 6.

\section{Radiolarians}

Rare to common, poorly preserved, nondiagnostic radiolarians were recovered from Section 1-1 through 


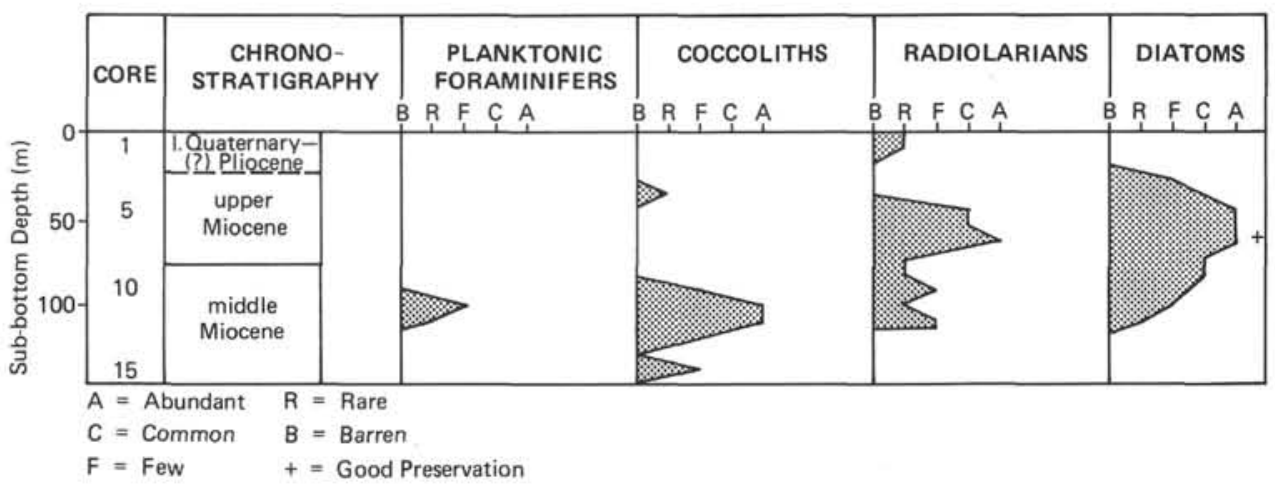

Figure 8. Plots of abundances of planktonic microfossils at Site 472.

Sample 1,CC. Cores 2 through 3 are barren; Cores 5 through 12 contain rare to abundant, poorly to well preserved radiolarian assemblages deposited in the late through middle middle Miocene. Sample 472-13,CC consists only of downhole contaminants.

The early Quaternary (? through late Pliocene) Sample 472-1-1, 1-2 cm contains a typical equatorial radiolarian assemblage (Amphirhopalum ypsilon, Ommatartus tetrathalamus, Pterocanium praetextum, P. prismatium, Theocorythium trachelium, $T$. vetulum, etc.), which lacks only the usually more frequent equatorial species Spongaster tetras.

The Miocene radiolarian assemblages are also composed of warm-water species. Section 4-1 yielded few, nondiagnostic radiolarians. Section 5-1 through Section 6-1, which contain Ommatartus penultimus, O. antepenultimus, O. hughesi, Stichocorys peregrina, S. delmontensis, and $S$. wolffii, can be assigned to the $O$. penultimus Zone. Because Riedel and Sanfilippo (1978) placed the boundary between $O$. penultimus and $O$. antepenultimus Zones immediately above the last occurrence of $O$. hughesi, the $O$. penultimus Zone would only include Section 5-1 at Site 472. Alternatively, this boundary can be drawn below the first appearance of $O$. penultimus. The lower upper Miocene $(O$. antepenultimus Zone) is indicated by the rare to common presence of $O$. antepenultimus, $O$. hughesi, rare to abundant occurrences of $S$. delmontensis and $S$. wolffii (Section 6-3 through Section 9-1), and by the absence of $O$. penultimus and $S$. peregrina. The boundary between middle and upper Miocene (i.e., the boundary between the Cannartus petterssoni and $O$. antepenultimus Zones) can either be drawn just below the first appearances of $O$. hughesi and $O$. antepenultimus (below Section 9-1) or above the last appearance of $C$. petterssoni (Section 8-1).

Upper middle Miocene (C. petterssoni Zone) is suggested for Section 9-3 (or Section 8-3) through Section 10-1, because of the presence of $C$. petterssoni and $C$. laticonus as well as less diagnostic species such as $S$. delmontensis, $S$. wolffii, and Cyrtocapsella japonica.

The deepest part of the succession at Site 472, below Section $10-1$, possibly belongs to the Dorcadospyris alata Zone, because it contains $C$. laticonus and lacks $C$. petterssoni and various species of Cyrtocapsella.

\section{Diatoms}

Diatoms are common to abundant in the upper and middle Miocene sediments at Site 472 . Cores 3 and 4 of Hole 472 contain relatively sparse assemblages that are similar to upper upper Miocene assemblages recovered at nearby Site 471 , as revealed by the presence of Denticula hustedtii, Thalassiosira antiqua, and Cussia species. Diatoms increase in abundance downhole in Core 5 and are generally common to abundant through Core 11. Diagenesis removed all but the robust diatoms from Cores 12 and 13.

Samples 472-5-1, 120-122 cm through 472-6-2, 130 $132 \mathrm{~cm}$ are assigned to the upper Miocene Thalassiosira antiqua Zone. The presence of Nitzschia porteri without $N$. miocenica in Sample 472-5-1, $140 \mathrm{~cm}$ indicates an age older than the upper part of paleomagnetic Epoch 7 and therefore older than Core 17 at nearby Site 471.

The interval from Sample 472-6-3, $130-132 \mathrm{~cm}$ through Sample $472-7-1,10-12 \mathrm{~cm}$ is correlated with Subzone a of the Denticula hustedtii Zone. A possible short hiatus between Samples 472-6-4, 20-22 cm and $472-6-5,10-12 \mathrm{~cm}$ is indicated by the presence of Thalassiosira burckliana in the former sample and the presence of Coscinodiscus temperei and Rhizosolenia miocenica in the latter sample. In middle latitudes of the North Pacific the first occurrence of $T$. burckliana is very high in Subzone a of the D. hustedtii Zone, whereas the last occurrences of $C$. temperei and $R$. miocenica are quite low in that subzone. Sample 472-6-5, $10-12 \mathrm{~cm}$ contains abundant, well preserved diatoms including common Denticula hustedtii. Sample 472-6-4, $20-22 \mathrm{~cm}$, however, displays poor diatom preservation with rare $D$. hustedtii. This apparent hiatus corresponds with a hiatus recognized at Site 469 and may reflect a regional paleoceanographic event such as a dissolution cycle or erosion associated with increased bottom currents.

Sample 472-7-1, 77-79 cm through Sample 472-12-1, 21-23 cm are assigned to the Denticula hustedtiiD. lauta Zone. This interval is further subdivided into the following subzones: Subzone d-Samples 472-7-1, $77-79 \mathrm{~cm}$ through 472-8-2, 120-122 cm; Subzone c-Samples 472-8-3, 30-32 cm through 472-10-2, 80-82 $\mathrm{cm}$; Subzone b-Samples 474-11-1, 35-37 cm through 
472-11-3, 35-37 cm; and Subzone a-Samples 472$11-4,28-30 \mathrm{~cm}$ through $472-12-1,21-23 \mathrm{~cm}$. The middle Miocene/upper Miocene boundary is placed in the upper part of Subzone c, in the lower part of Core 8 . Because preservation is poor in the lower part of the hole, the correlation of Subzone a is tentative.

Although the middle- to high-latitude diatom zonation was employed at this site, low-latitude diatoms are a consistent component of the assemblage.

\section{Foraminifers}

Foraminifers are sparse and moderately well preserved in Cores 11 and 12 of Hole 472. Planktonic taxa encountered include Globigerinoides sacculifer, Globigerina bulloides, G. obesa, Globoquadrina altispira, and Orbulina universa. The occurrence of Globorotalia praefohsi in Section 11-1, indicates at least part of Core 11 is referable to Zone N11.

\section{SEDIMENT ACCUMULATION RATES}

Selected coccolith (C), radiolarian (R), diatom (D), and planktonic foraminiferal $(\mathrm{F})$ events are used to construct the sediment accumulation rate curve (Fig. 9) for Site 472 . The plot indicates rates of about $5 \mathrm{~m} / \mathrm{m}$.y. for the Quaternary through latest Miocene (Cores 1-4) and about $8 \mathrm{~m} / \mathrm{m} . \mathrm{y}$. for most of the late Miocene and the middle Miocene. No significant stratigraphic gaps are indicated.

\section{GEOCHEMICAL MEASUREMENTS}

\section{Interstitial Water}

The salinity, chlorinity, alkalinity, and calcium and magnesium concentrations of the pore waters from three samples were determined on board. These samples span the entire sediment thickness at Site 472 . The sedimentary column at the site is very thin, and the pore water chemistry shows only very minor changes from sea water. There is a slight increase in calcium and decrease in magnesium in the pore waters (Fig. 10).

\section{Calcium Carbonate Content}

Calcium carbonate contents of samples from Hole 472 determined by the carbonate-bomb technique are included with the core descriptions in this chapter and plotted in Figure 11. Like Site 471, this site is dominated by noncalcareous pelagic and biogenic sediments; all but three samples from Site $\mathbf{4 7 2}$ are noncalcareous. Unit 3 contains some siliceous nannofossil clays and oozes, which contain up to $50 \% \mathrm{CaCO}_{3}$.

\section{PHYSICAL PROPERTIES}

Figure 11 summarizes the physical-properties data at Site 472. Although we recognize three lithologic units in the sedimentary section, density and velocity profiles do not show corresponding breaks. On the contrary, both density and velocity remain constant throughout the sedimentary section $\left(1.47 \mathrm{~g} / \mathrm{cm}^{3}\right.$ and $1.50 \mathrm{~km} / \mathrm{s}$, respectively) and increase abruptly only at the top of the basalt at 112 meters. The average density and velocity of the basalt are $2.79 \mathrm{~g} / \mathrm{cm}^{3}$ and $5.51 \mathrm{~km} / \mathrm{s}$, respectively. The impedance contrast for the boundary between sediment and basalt is 0.75 .

We made one run with the $\mathrm{U} / \mathrm{K}$ heat-flow probe, stopping at 88 meters in the sediment for 20 minutes, then raising the probe to the mudline and holding for 10 minutes to get a bottom-water temperature. Figure 12 displays the results. The bottom-water temperature was

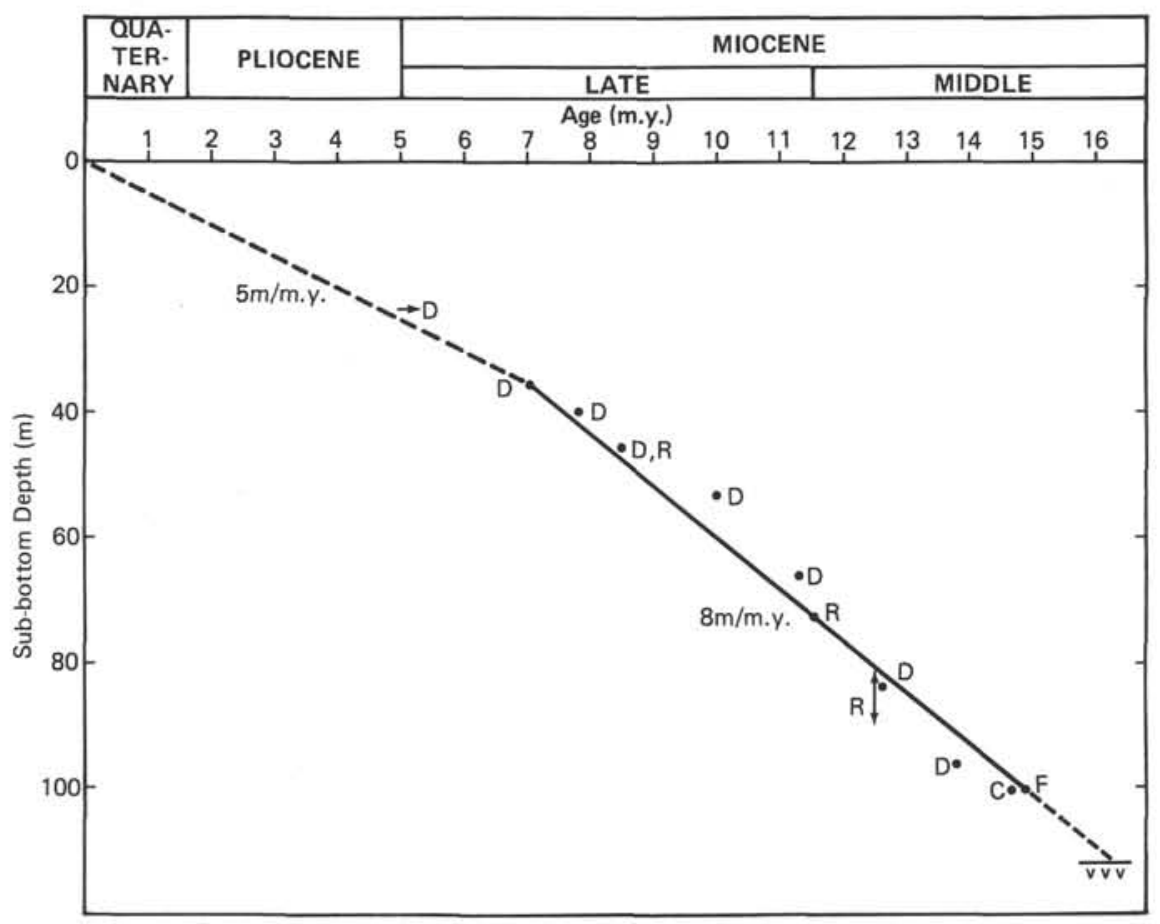

Figure 9. Sediment accumulation rates, Site 472. 


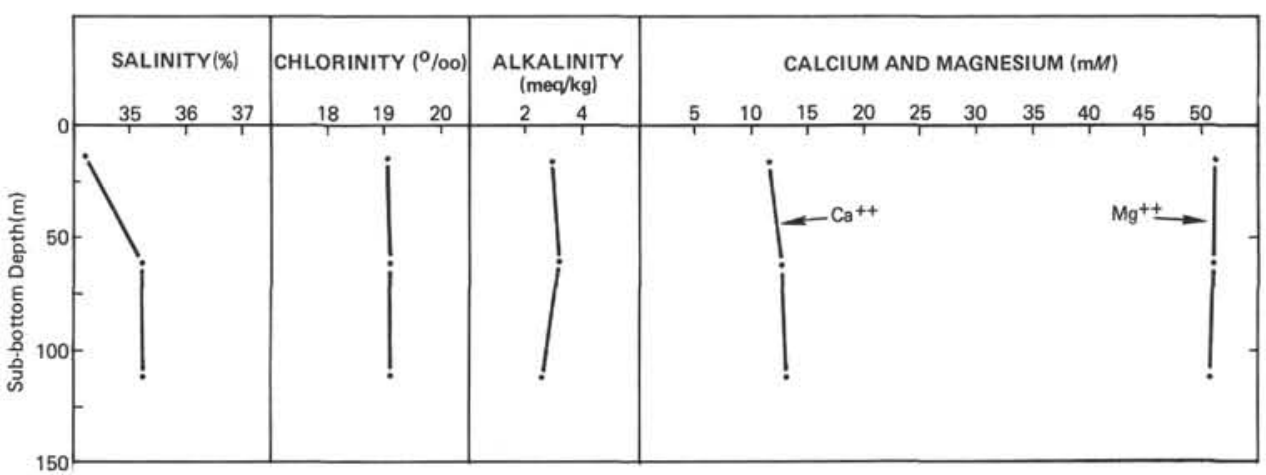

Figure 10. Interstitial water profiles, Site 472.

slightly variable, averaging about $1.9^{\circ} \mathrm{C}$. The sediment temperature at a depth of 88 meters increased slightly from $14^{\circ} \mathrm{C}$ to $14.3^{\circ} \mathrm{C}$ during the measurement. The computed geothermal gradient is $141^{\circ} \mathrm{C} / \mathrm{km}$. The approximate heat flow, assuming a value of $1.9 \mathrm{mcal} / \mathrm{cm} \mathrm{s}$ ${ }^{\circ} \mathrm{C}$ for the thermal conductivity of the sediment is 2.7 HFU (heat-flow units).

\section{CORRELATION OF REFLECTION PROFILE WITH DRILLING RESULTS}

Correlation of the reflection profile obtained by the Glomar Challenger approaching Site 472 (Fig. 5) and the drilling results are shown in Figure 13. The upper units of Quaternary to Miocene clay and clayey diatomaceous ooze appear as the light upper layer on the profile. The diatomaceous oozes and diatom-rich interbeds within this clay-rich part of the section probably produce the several sets of strong paired reflectors within this upper acoustic unit. The underlying acoustic unit, which includes the lower part of Lithologic Unit 2 and all of Unit 3, appears as a darker, more closely spaced, and more continuous sequence of reflectors. In this sequence, the number of diatomaceous and nannofossil interbeds increases, which probably accounts for the increased number of strong reflectors. Although basaltic basement at $0.15 \mathrm{~s}$ sub-bottom shows only a weak contrast with the overlying sedimentary layers, it can be distinguished by its irregular relief.

\section{CONCLUSIONS}

1. Site $\mathbf{4 7 2}$ provides a biostratigraphic reference section for middle and lower upper Miocene siliceous microfossils at the southern, distal end of the California
Current. The section contains a mixture of high- and low-latitude siliceous assemblages.

2. The oldest sediments contain microfossils of this Sphenolithus heteromorphus Zone, $16 \pm 0.5$ m.y. old; this age is also indicated by magnetic anomalies at the site. The oldest sediments at this site are about the same age as those at Site 471 . The sediments are underlain by fresh, olivine-bearing pillow basalt, brecciated in the upper part.

3. The transition downsection from unfossiliferous red clay in Core 3 to highly siliceous ooze in Core 5 occurred in the latest Miocene, about 7 to $5 \mathrm{~m} . \mathrm{y}$. ago. This transition is attributed to either a narrowing of upwelling areas in the northeastern Pacific about 7 m.y. ago or to tectonic translation of Site $\mathbf{4 7 2}$ from a high- to lowproductivity region at this time. The transition that took place at this site 7 to 5 m.y. ago occurred in the same time interval as did the hiatus in the biostratigraphic record at Site 470 . The upper part of the siliceous sequence at Site 472 is the same age as the base of the siliceous sequence at Site 471 .

\section{REFERENCES}

Atwater, T., 1970. Implications of plate tectonics for the Cenozoic tectonic evolution of western North America. Geol. Soc. Bull. Am., 81:3513-3536.

Chase, C. G., Menard, H. W., Larson, R. L., et al., 1970. History of sea floor spreading west of Baja California. Geol. Soc. Am. Bull., $81: 491-498$.

Chase, T. E., Menard, H. W., and Mammerickz, J., 1974. Bathymetry of the North Pacific. Scripps Inst. Oceanogr. and Inst. of Marine Resources Chart No. 9 of 10.

Riedel, W. R., and Sanfilippo, A., 1978. Stratigraphy and evolution of tropical Cenozoic radiolarians. Micropaleontology, 21:61-96.

Sclater, J. G., Anderson, R. N., and Bell, M. L., 1971. Elevation of ridges and evolution of the central eastern Pacific. J. Geophys. Res., 76:7888-7915. 


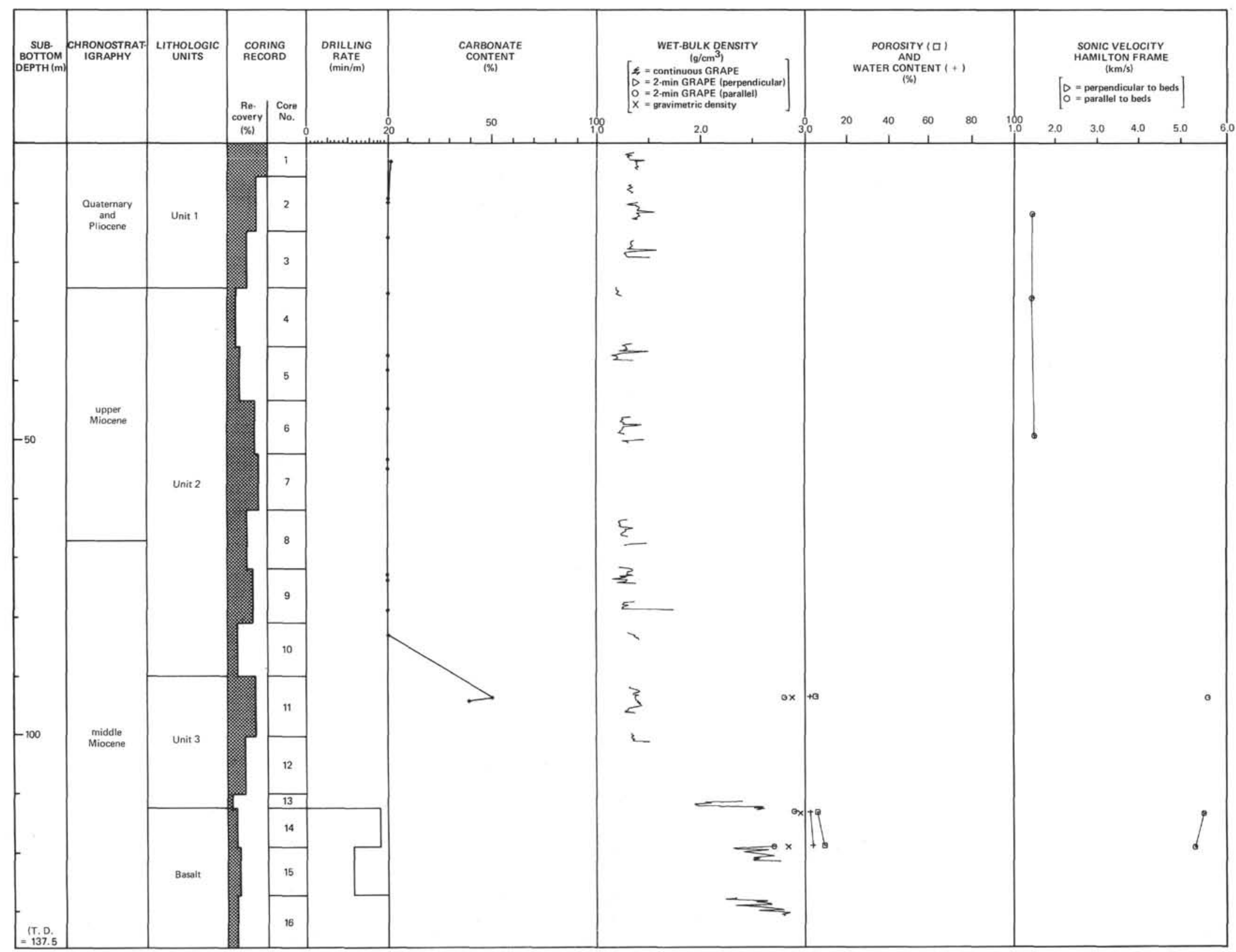




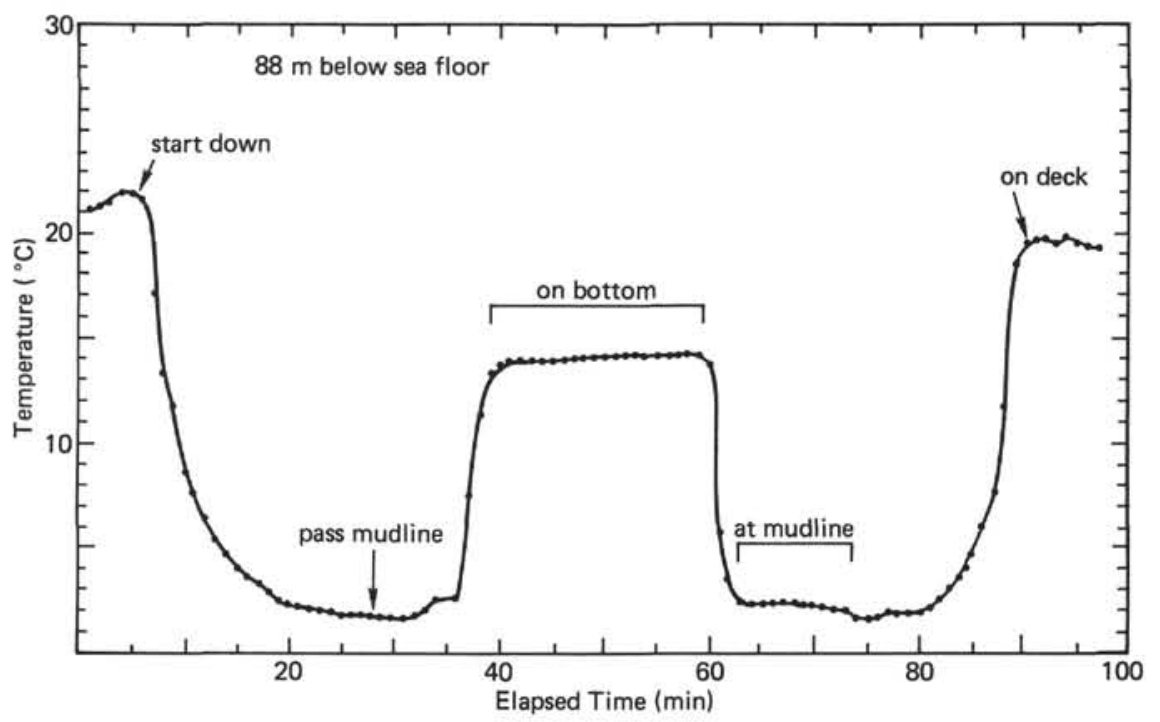

Figure 12. Heat-flow-probe run, Site 472. (See text for explanation.)

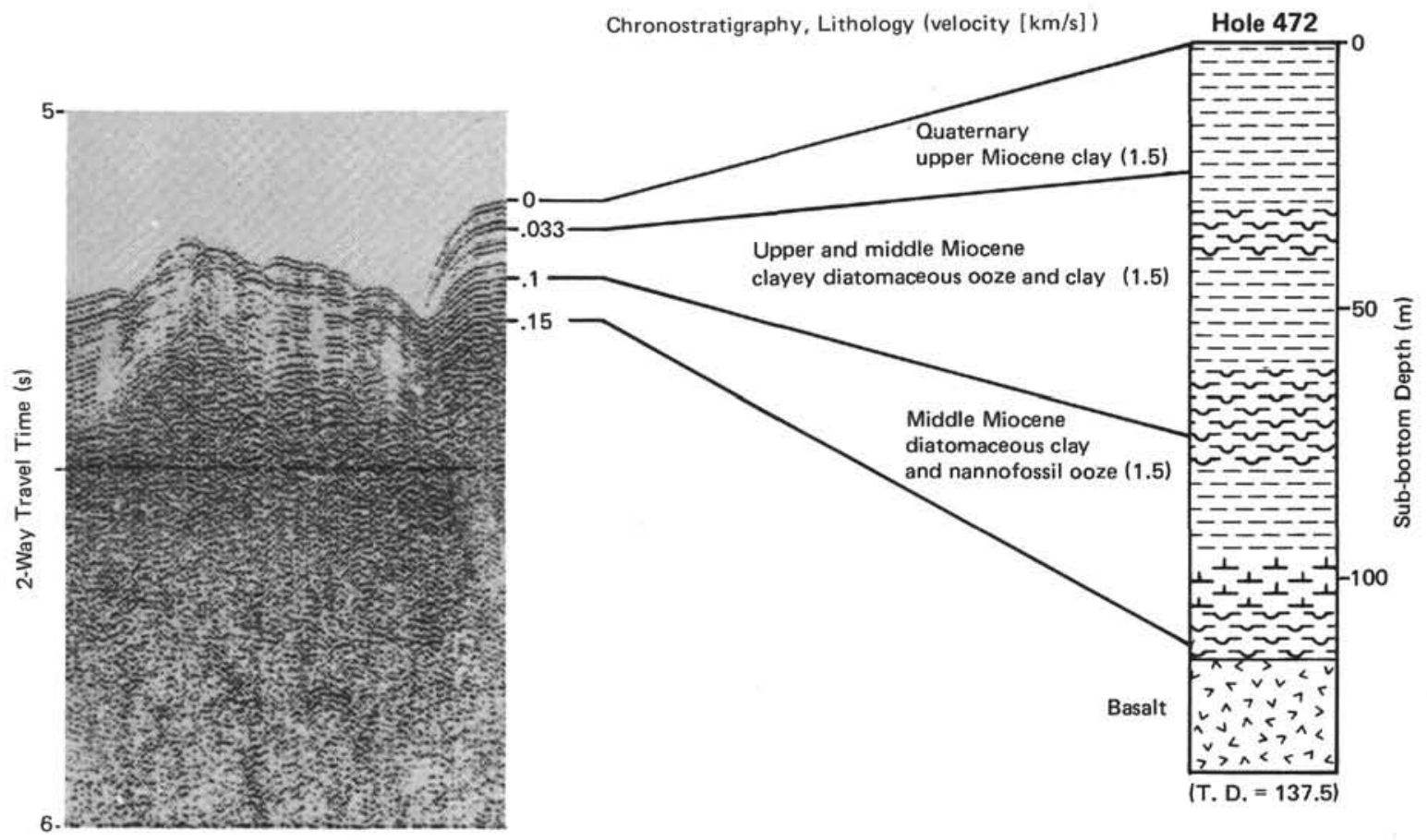

Figure 13. Correlation of Challenger seismic-reflection profile with lithologic units at Site 472. 

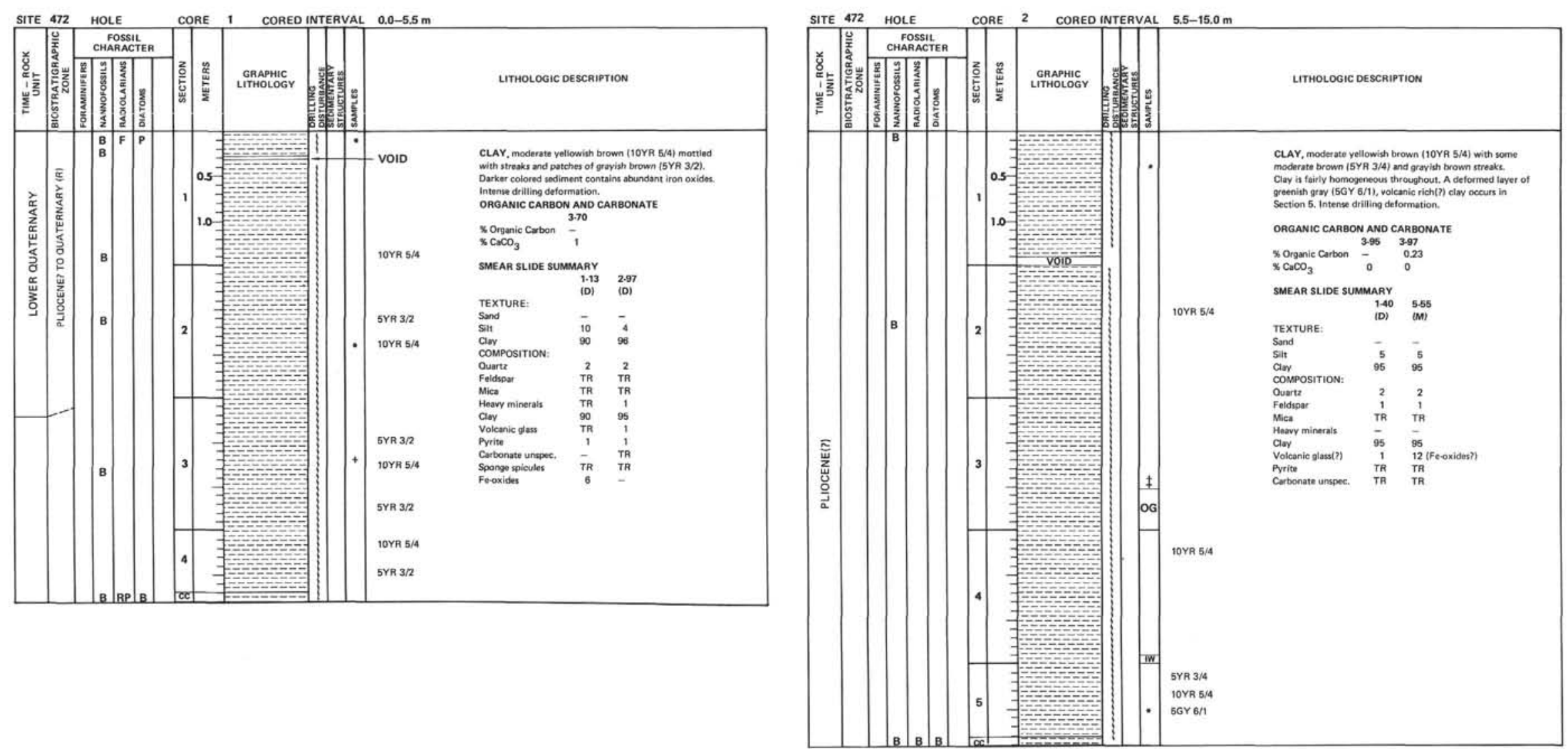


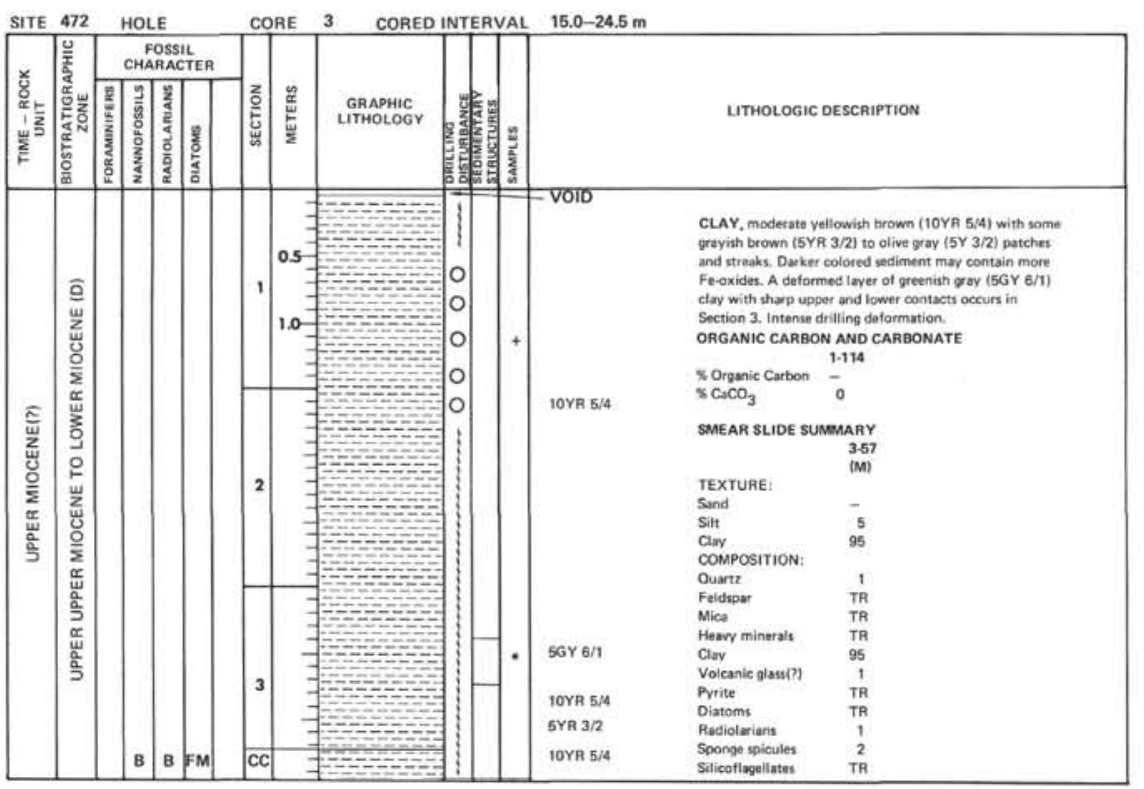

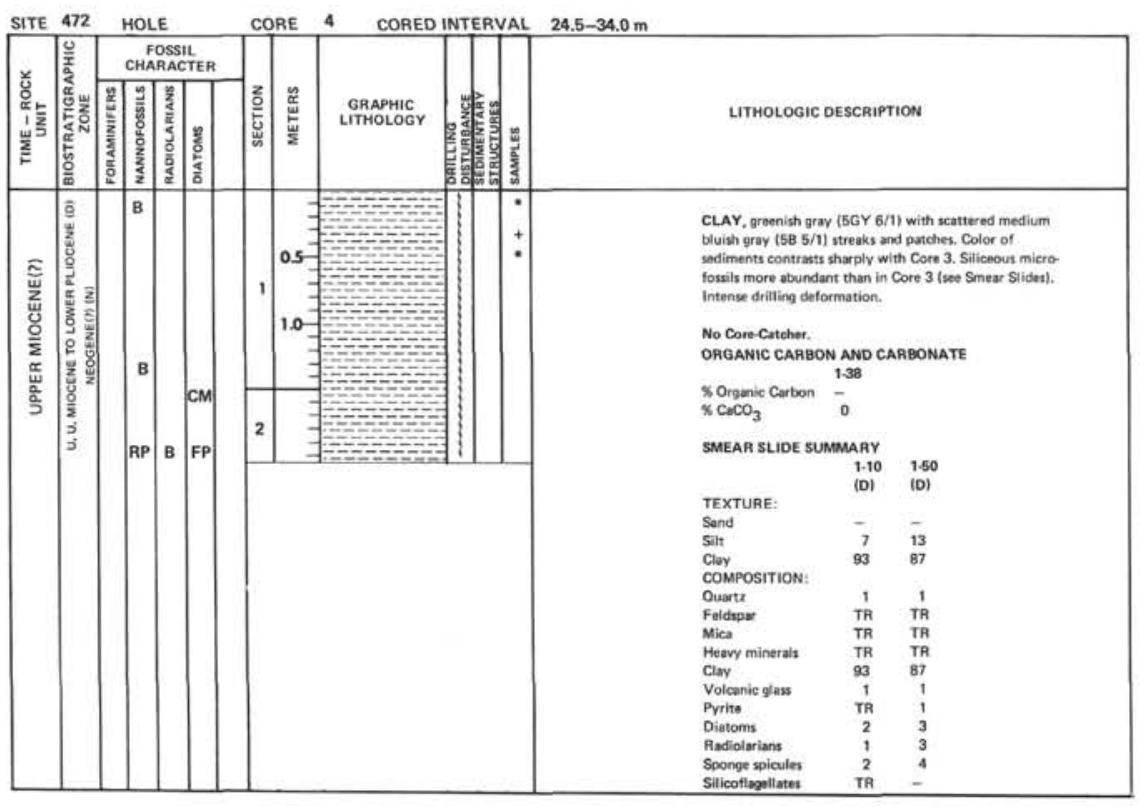

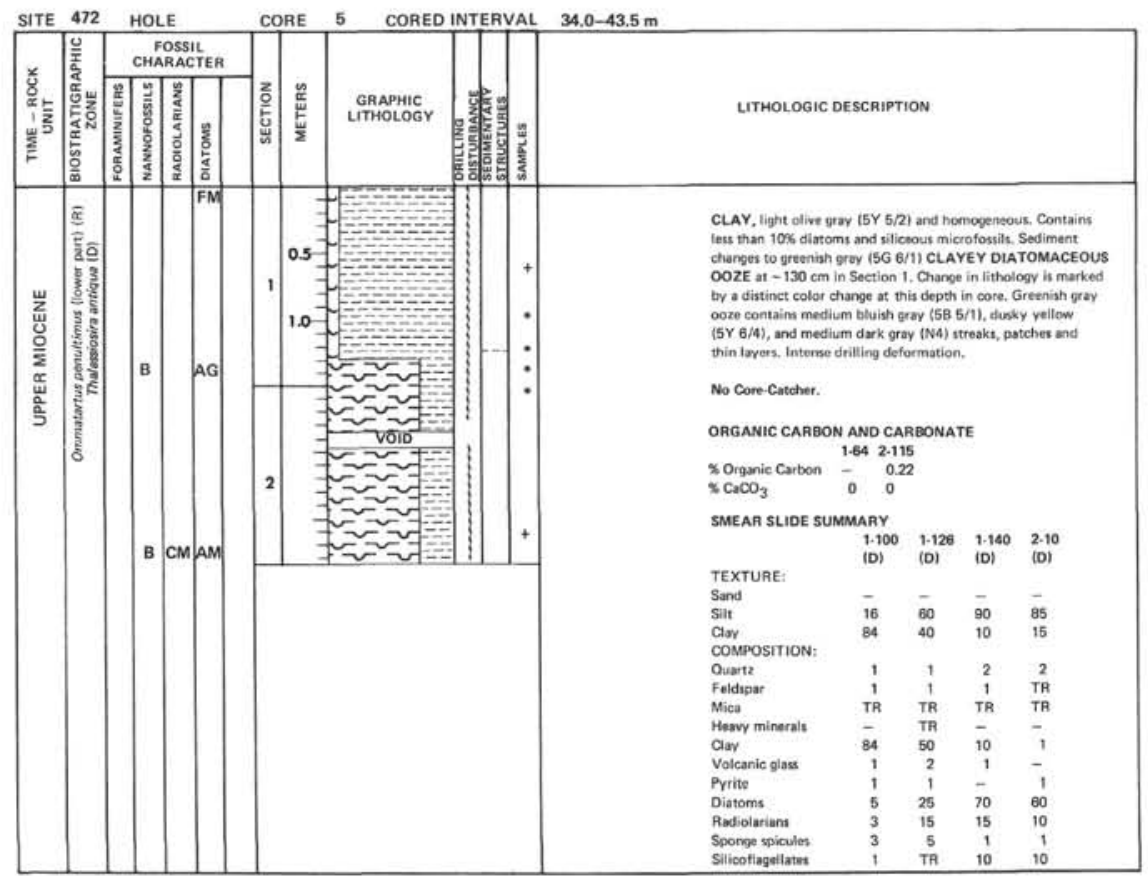



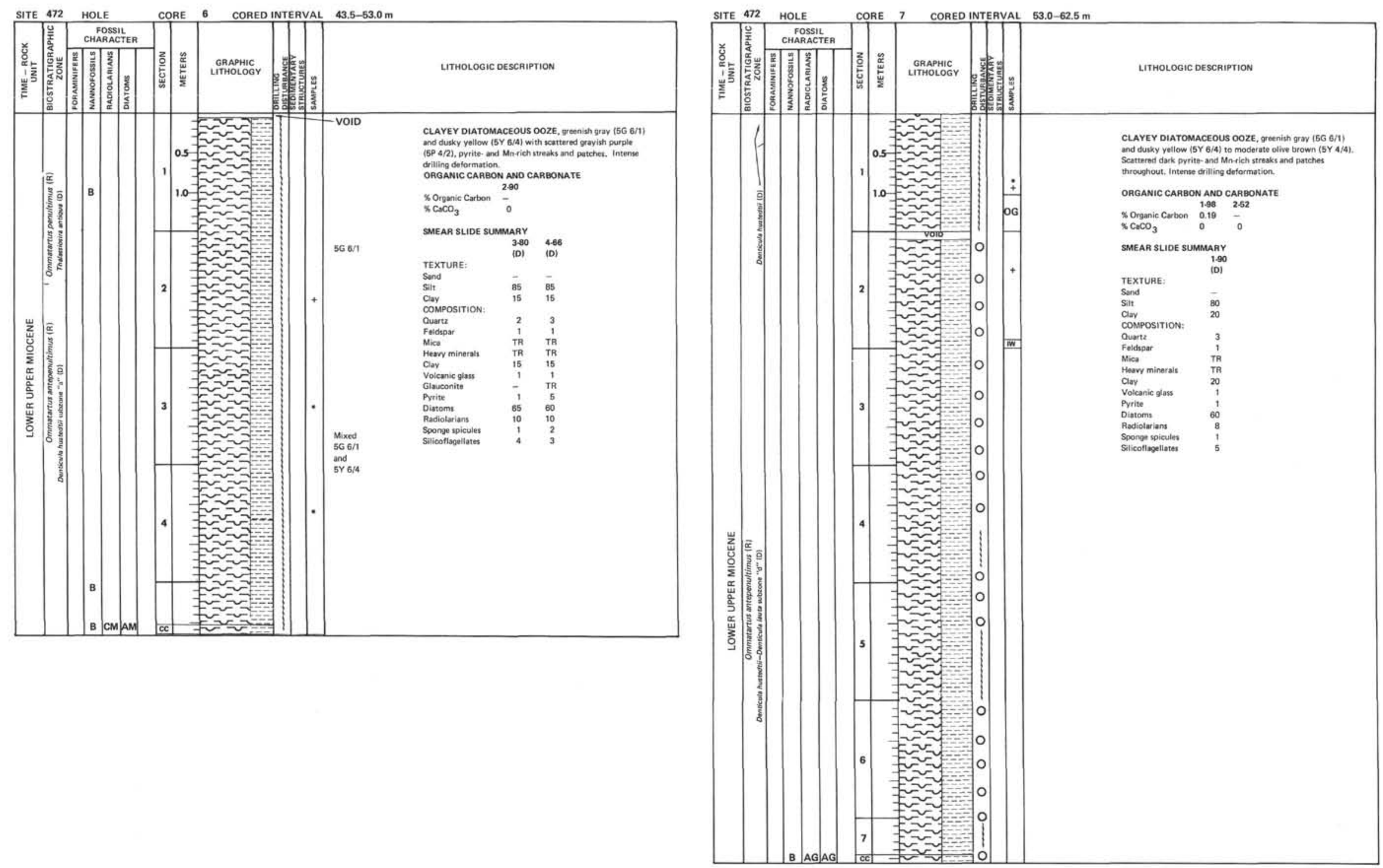

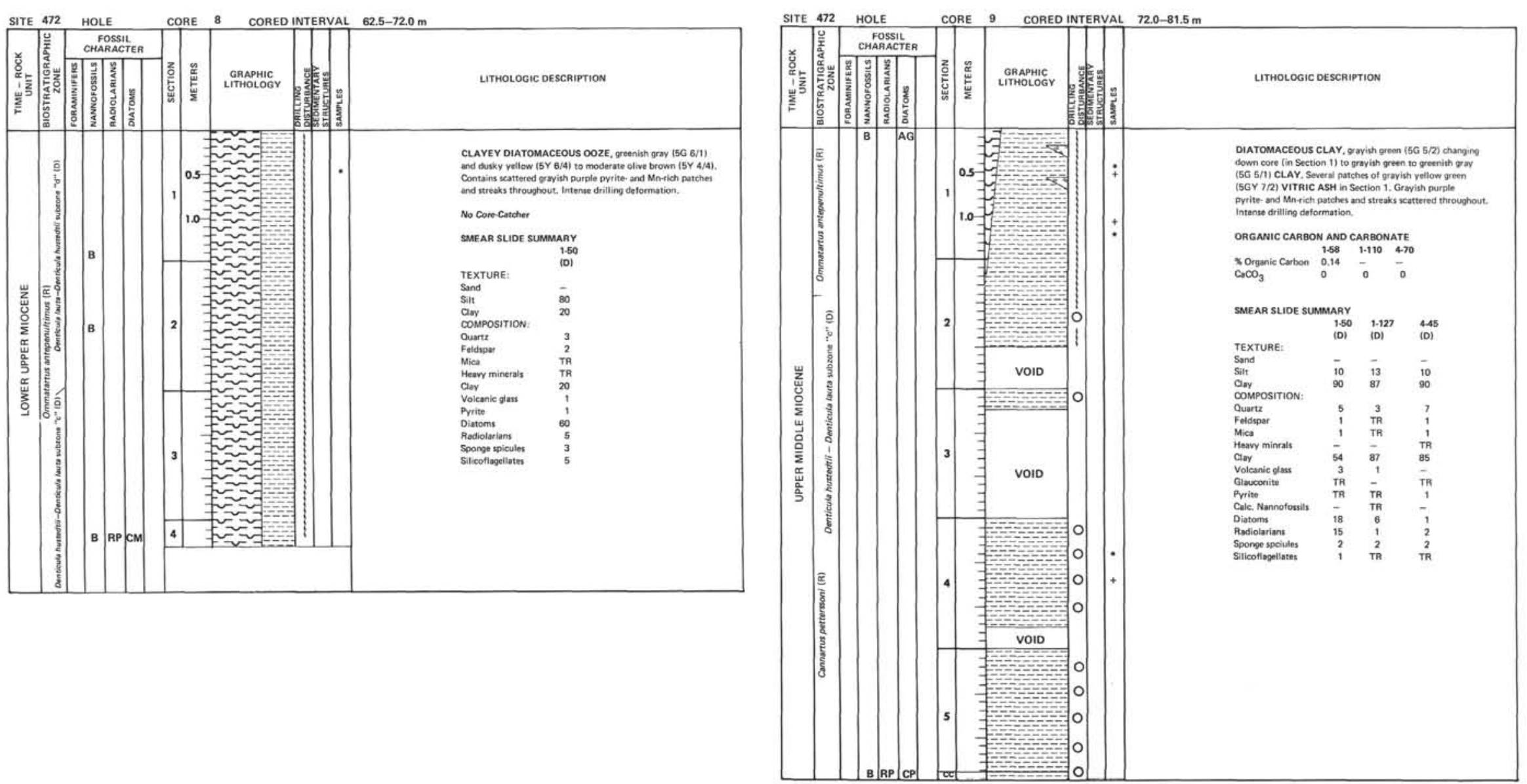


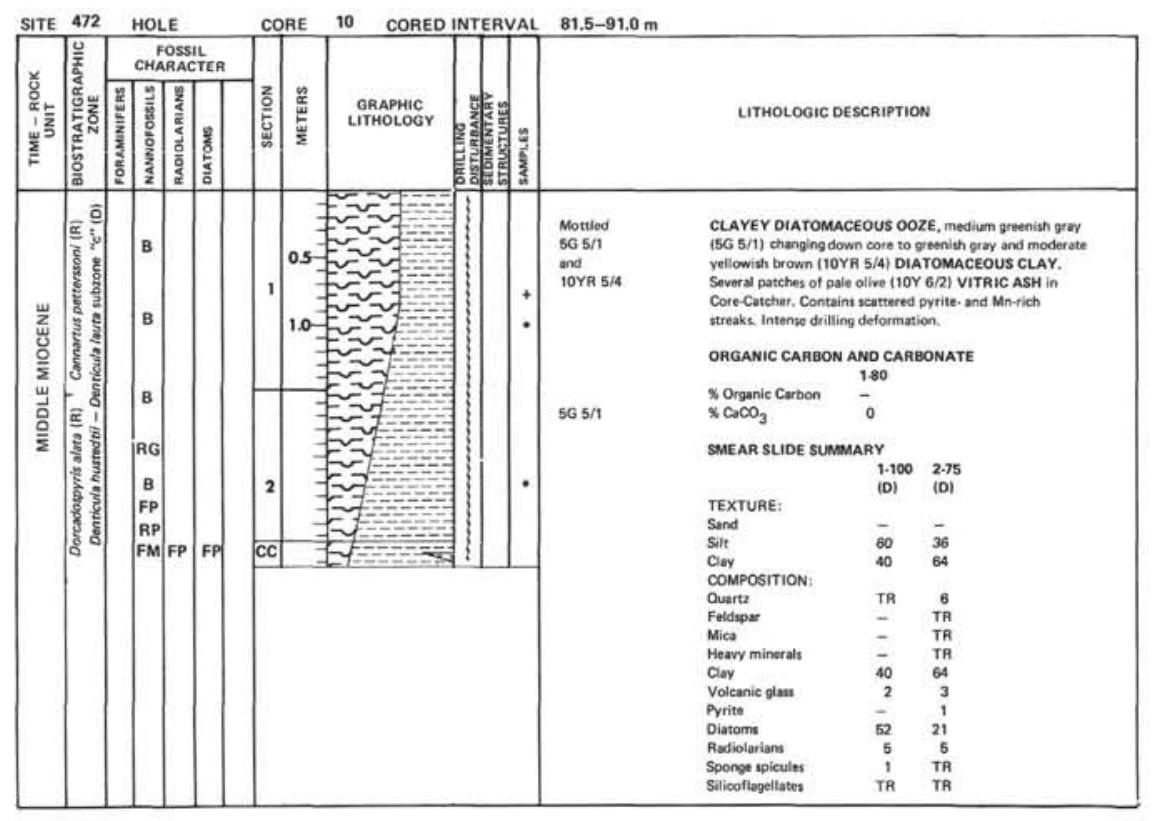

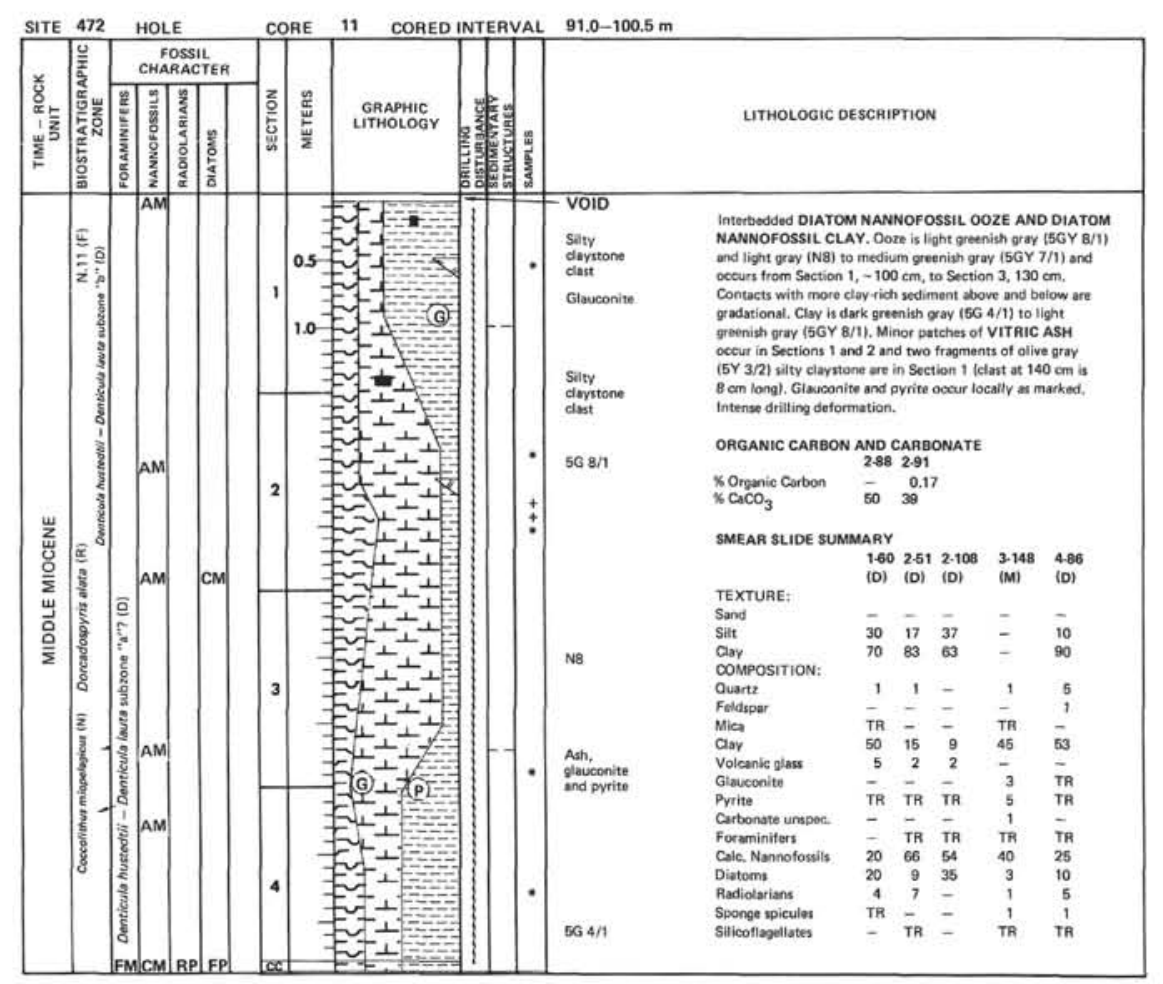



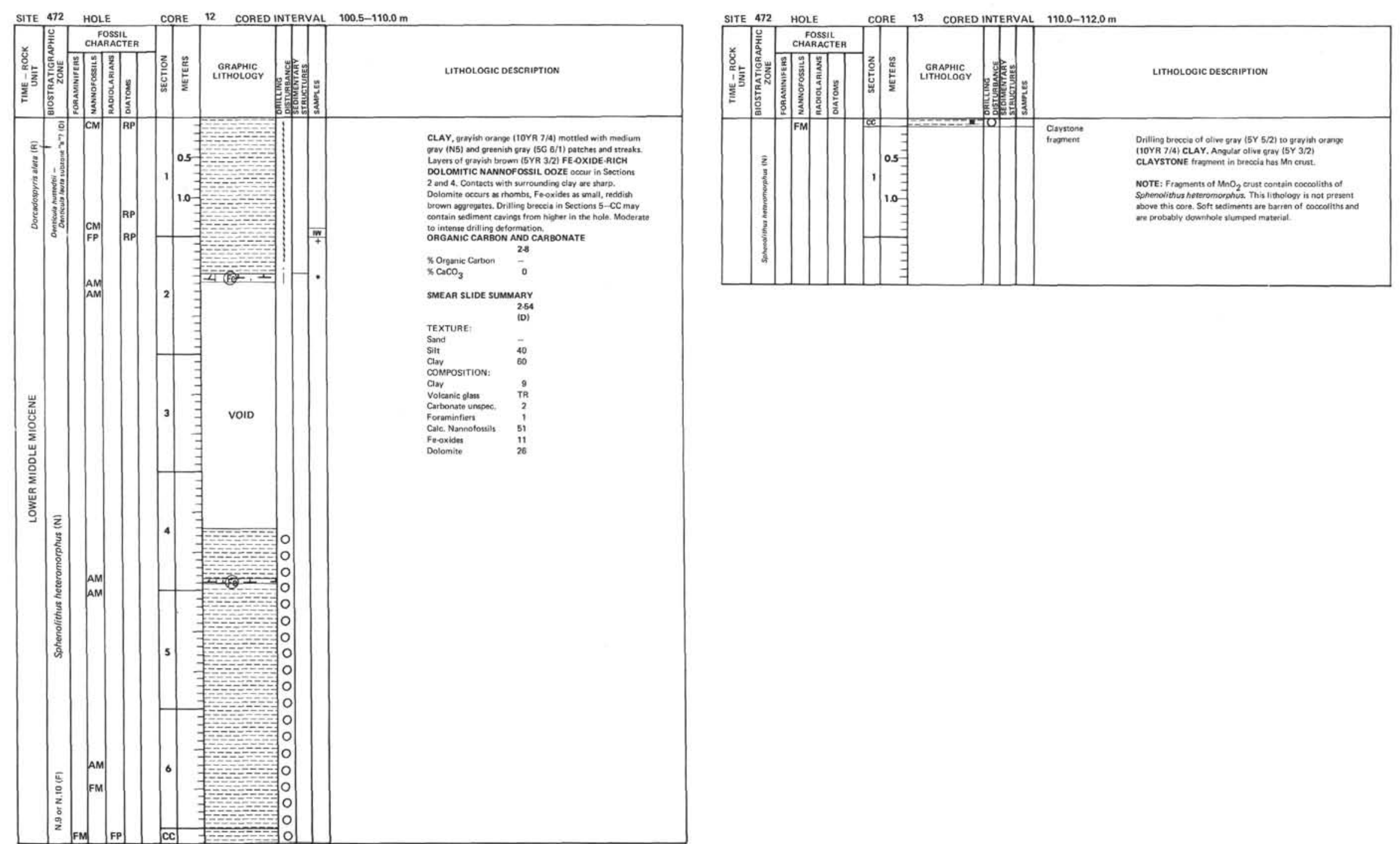


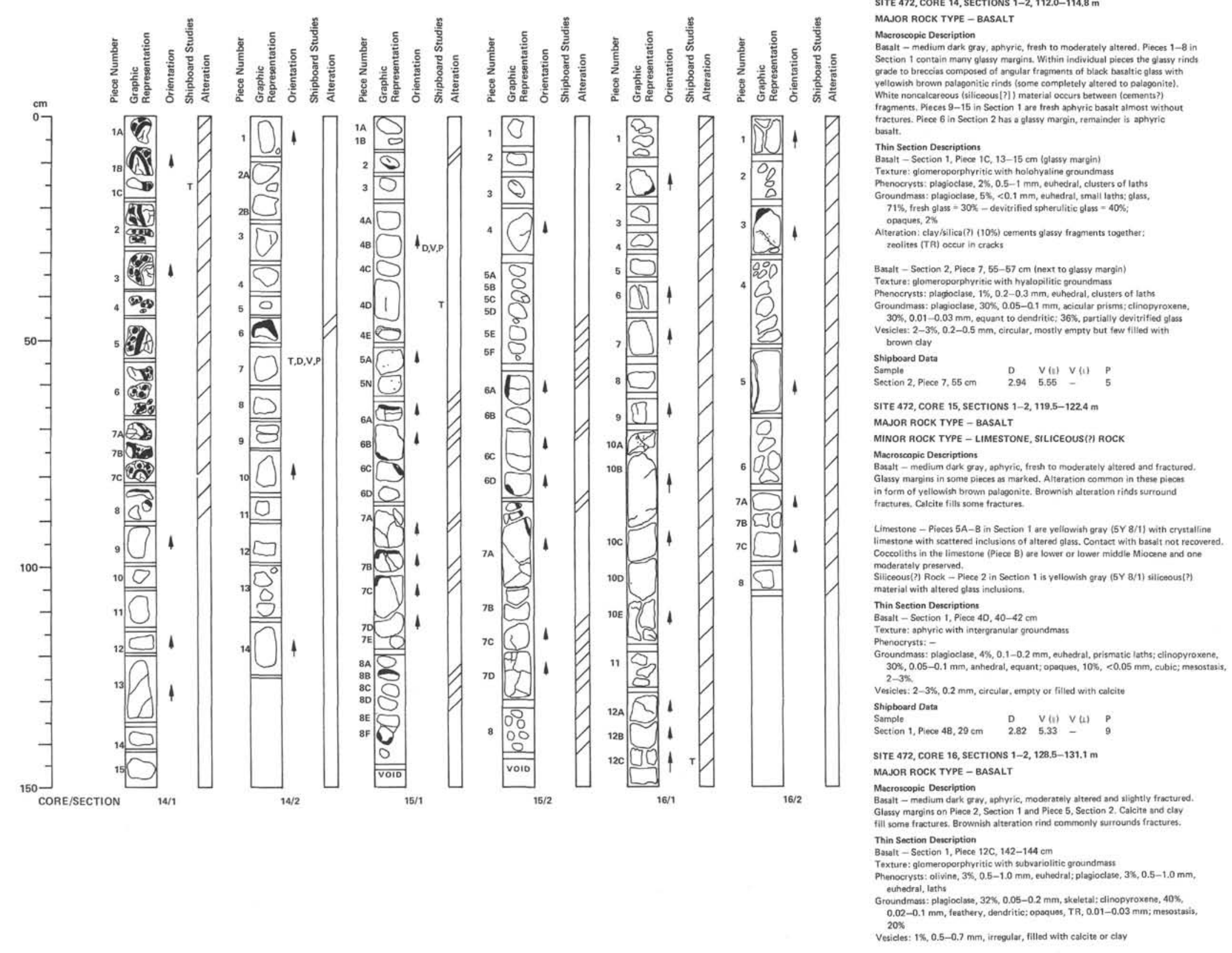




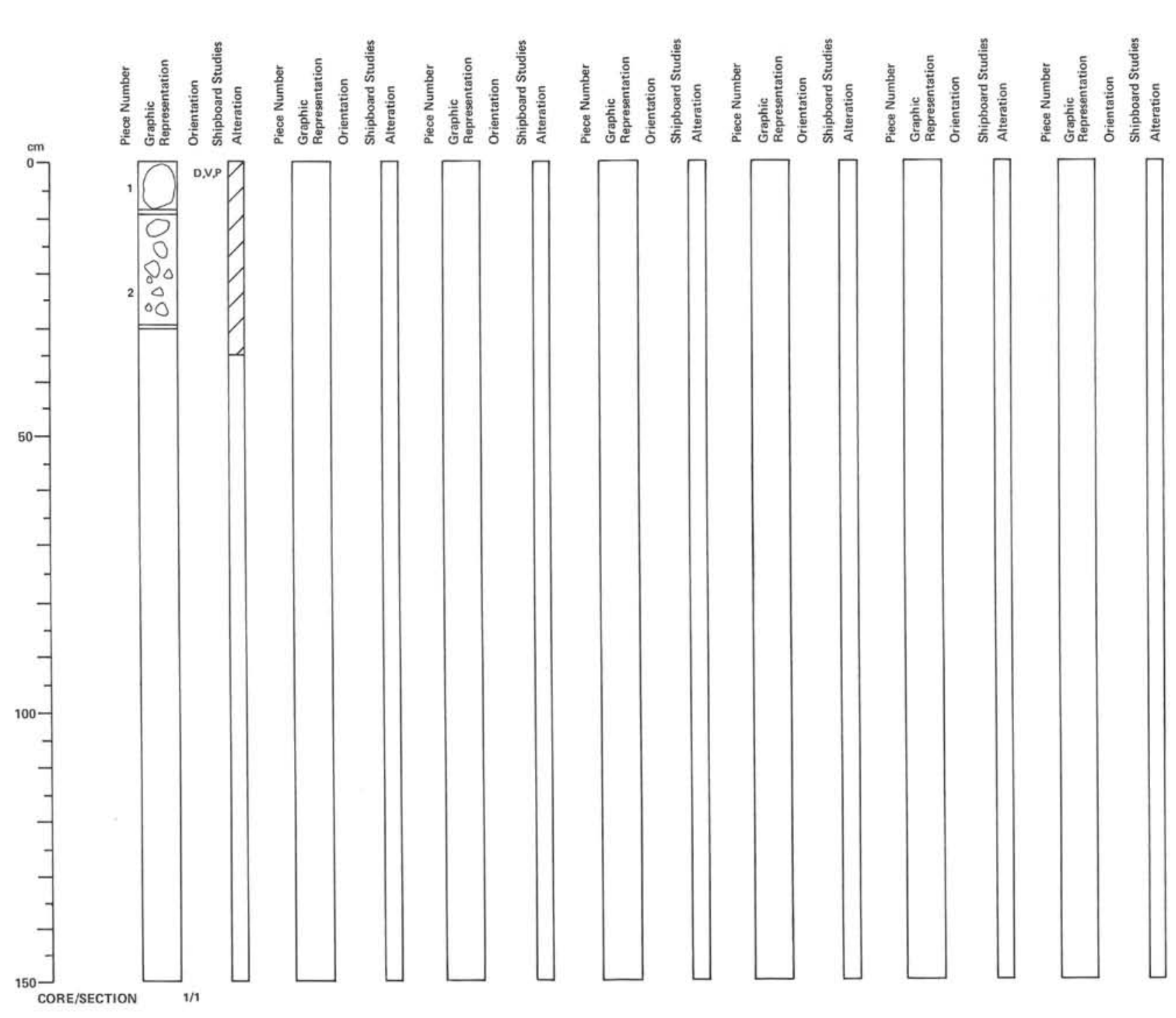

MAJOR ROCK TYPE - BASALT

Macroscopic Descrip
Basalt - medium dar

Basait - medium
vesicles $<<0.5 \mathrm{~mm} /$
shiphout

$\begin{array}{lllll}\text { Shipboard Data } & D & v(1) & v(t) & p \\ \text { Sample } & \text { Section 1, Piece 1, } 3 \mathrm{~cm} & 2.86 & 5.65 & -\end{array}$ 


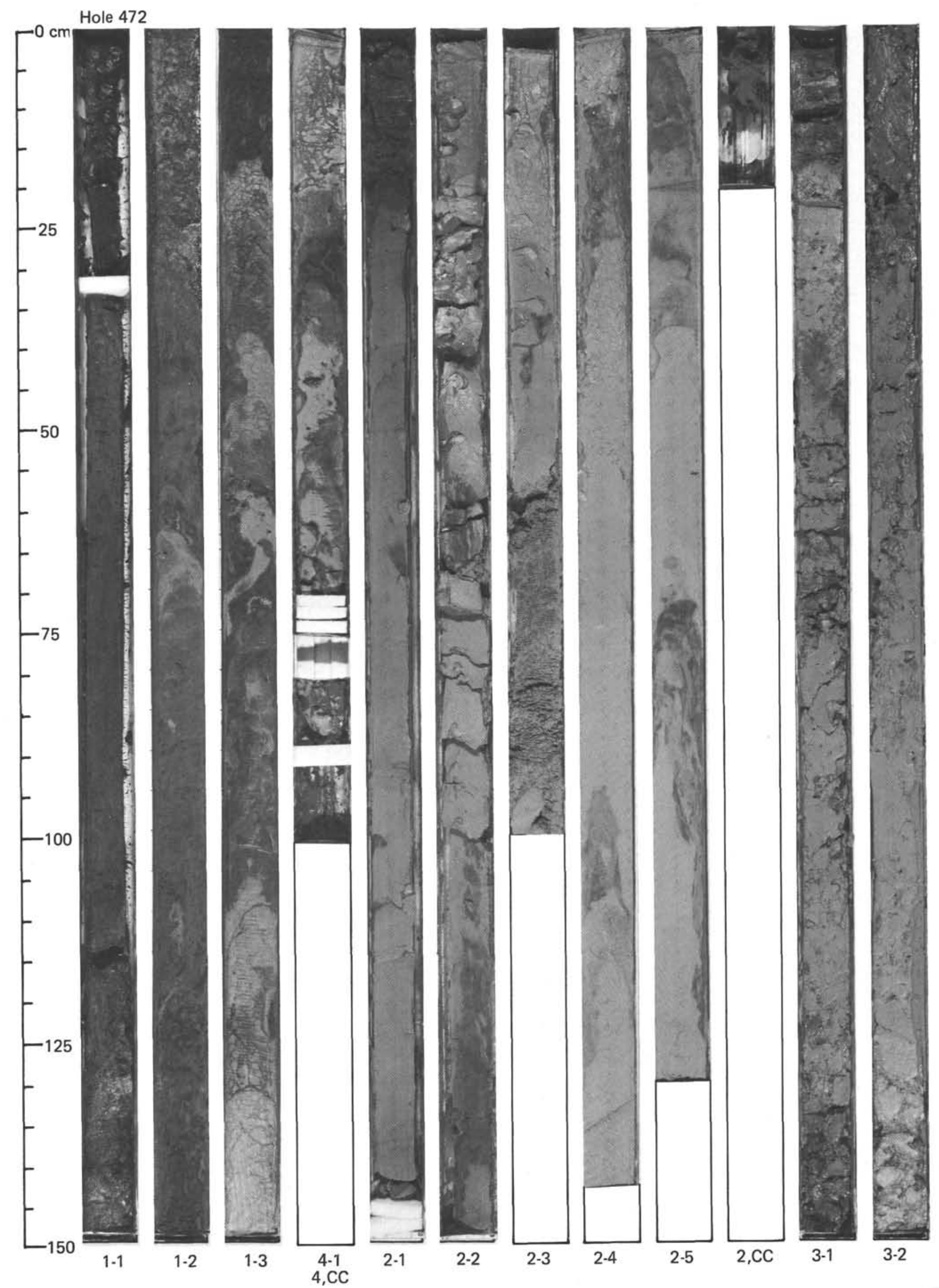




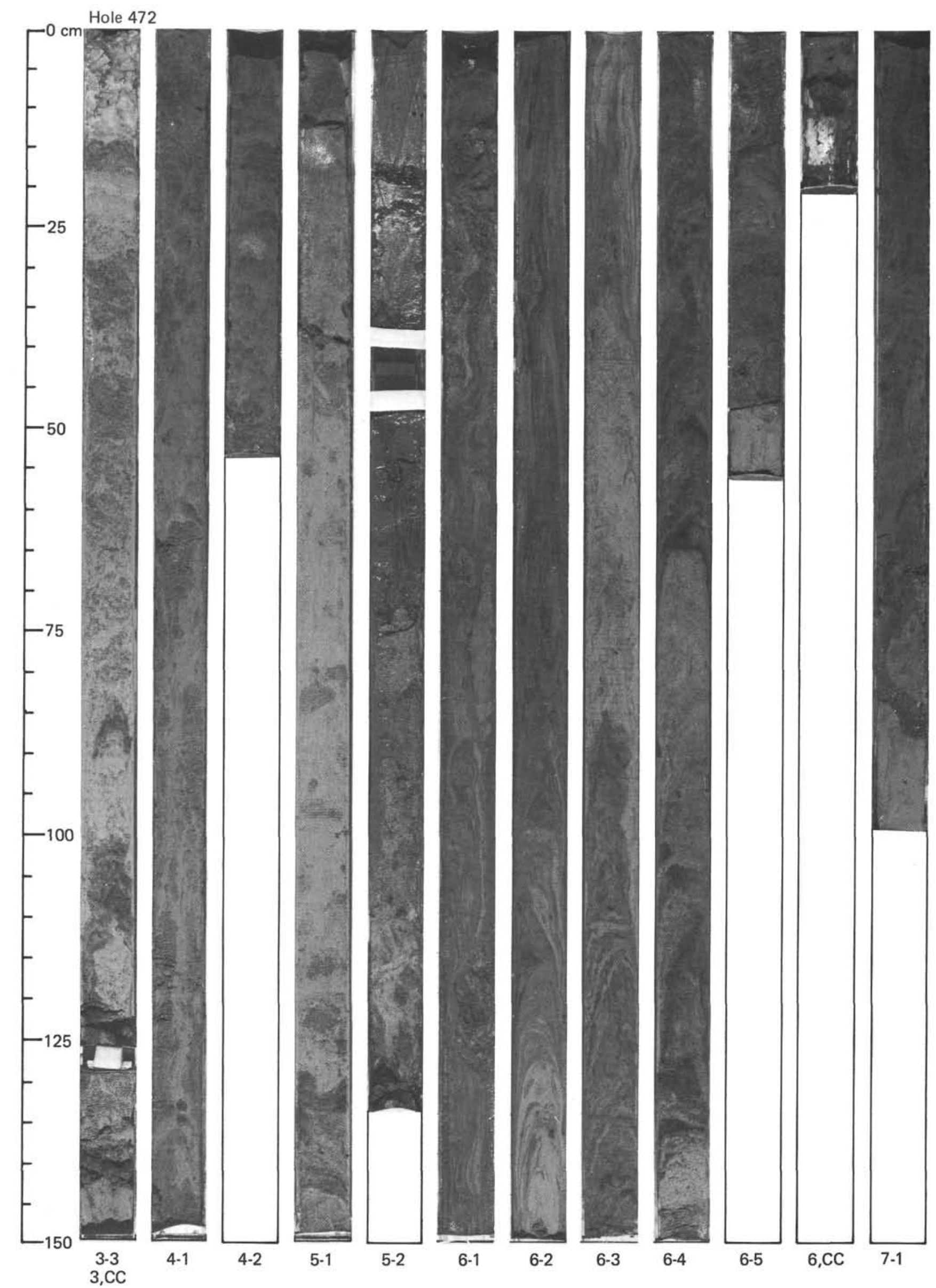









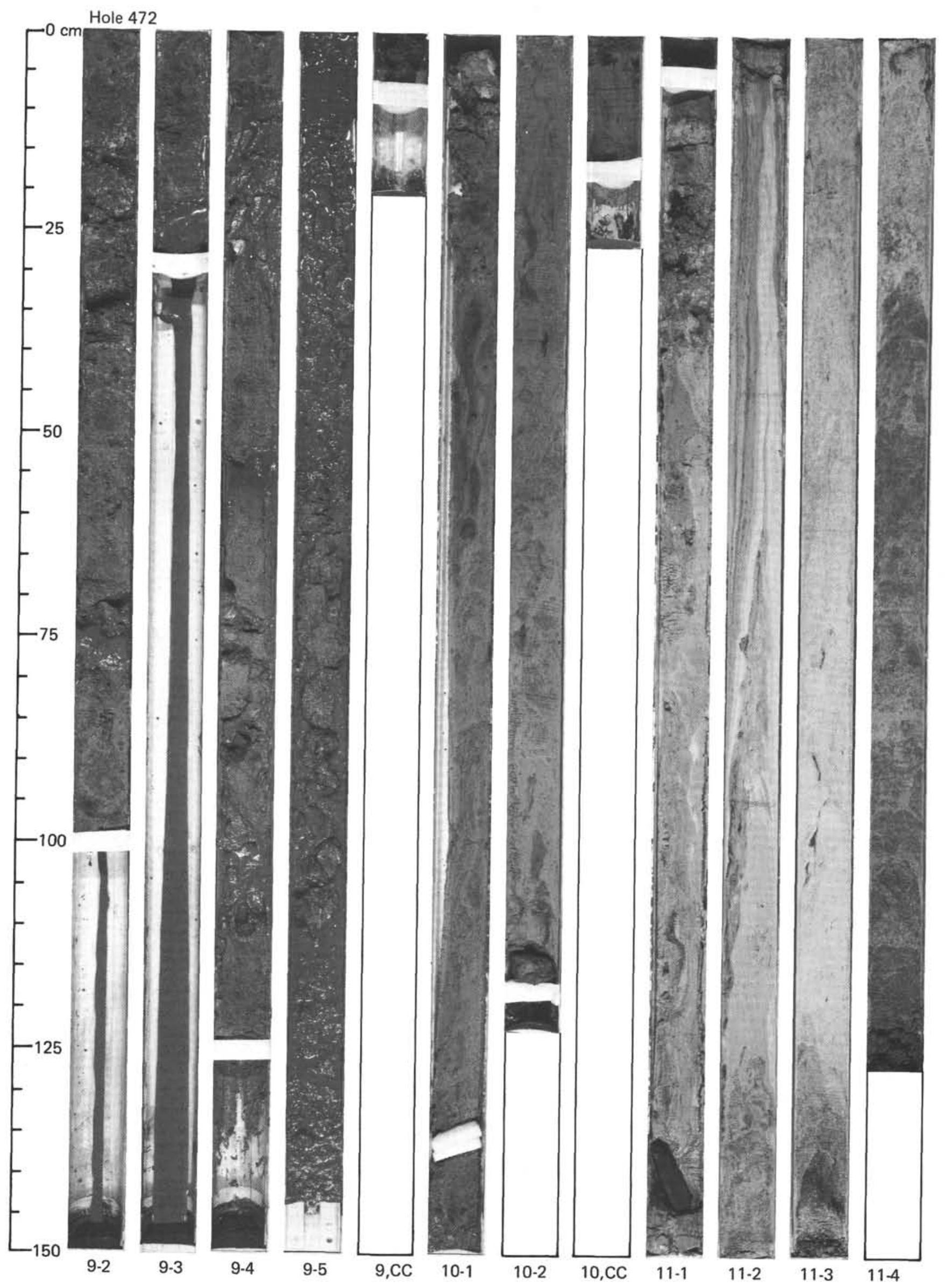



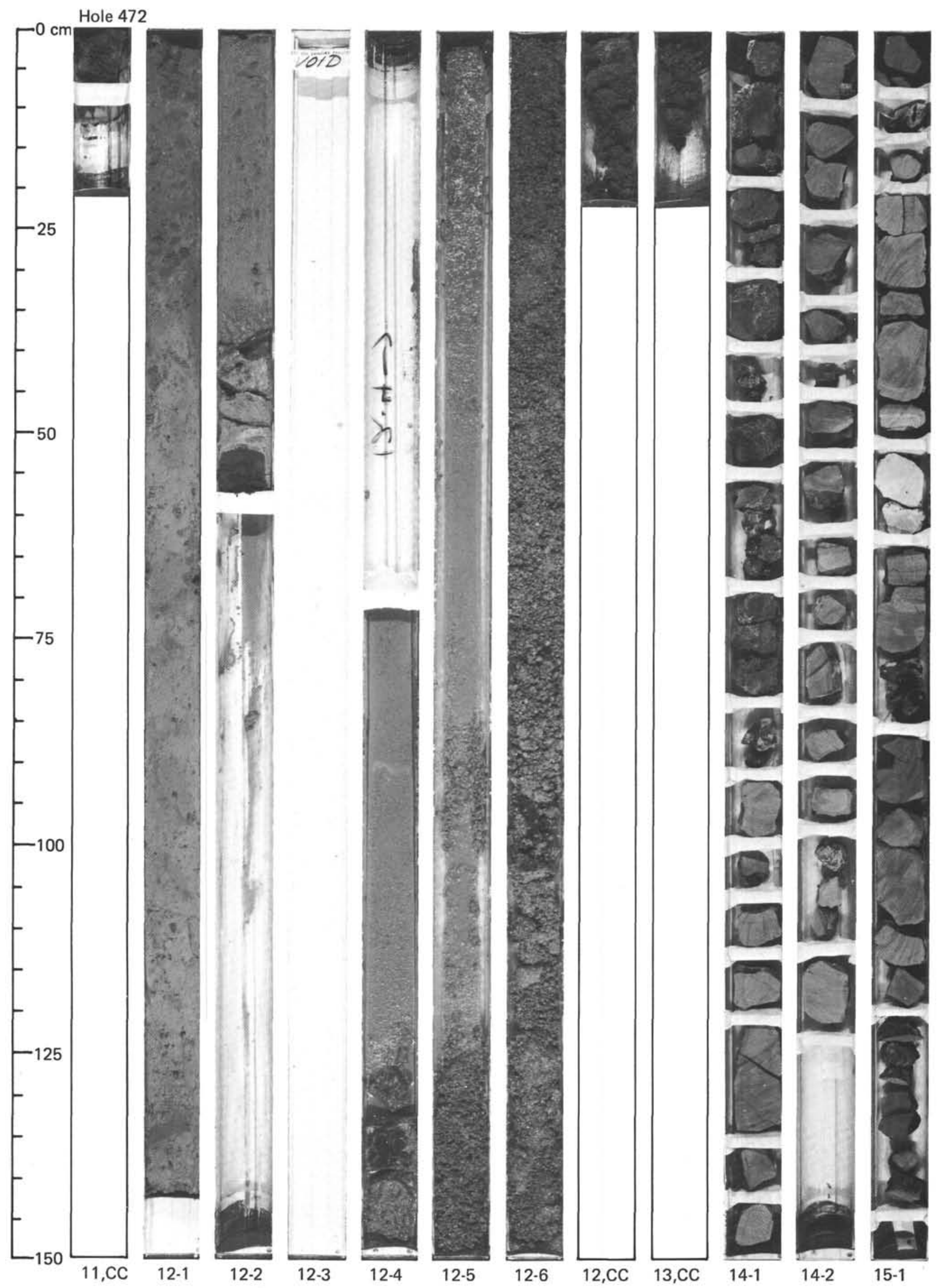

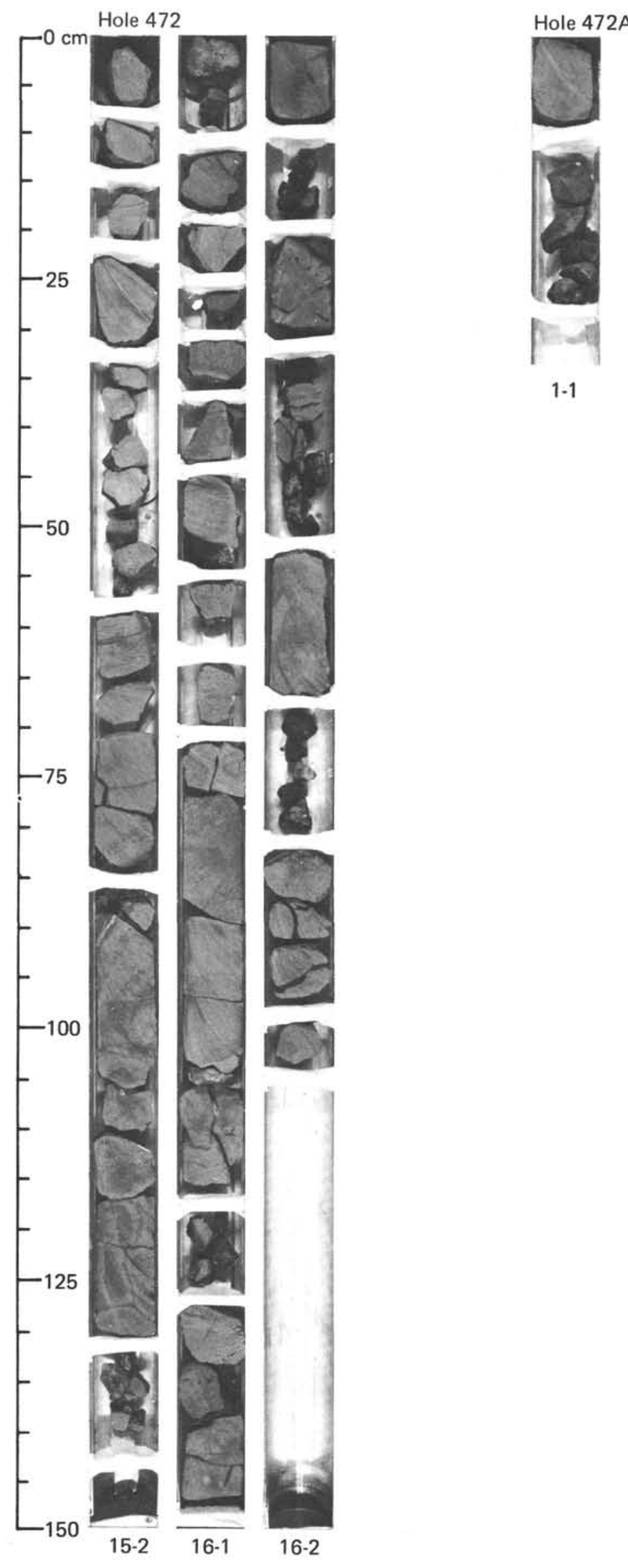

$1-1$ 